\title{
In Situ Protein Phosphorylation in Hippocampal Tissue Slices
}

\author{
Rick K. Yip ${ }^{a}$ and Paul T. Kelly \\ Department of Neurobiology and Anatomy, University of Texas Health Science Center, Houston, Texas 77225
}

\begin{abstract}
We have studied the subcellular distribution of phosphoproteins in intact hippocampal slices and examined factors that regulate their phosphorylation and dephosphorylation in situ. The presence of $\mathrm{Ca}^{2+}$ in slice equilibration and prelabeling buffers and high- $\mathrm{K}^{+}$-induced depolarization markedly increased ${ }^{32} \mathrm{P}_{i}$ incorporation into endogenous proteins. $\mathrm{Ca}^{2+-}$ stimulatory effects were significantly reduced by $\mathrm{Ca}^{2+}$-channel blockers and the calmodulin antagonist $W-13$. Certain proteins were dephosphorylated in situ, and their dephosphorylation was dependent on both $\mathrm{Ca}^{2+}$ and depolarization. A number of proteins phosphorylated in situ was similar to those previously characterized in synaptic fractions phosphorylated in vitro. Many phosphoproteins were identified on the basis of molecular weight, isoelectric point, immunoreactivity, and phosphopeptide mapping; these included the $87 \mathrm{kDa}$ substrate of protein kinase $\mathrm{C}$, synapsin I, the $\mathbf{5 0}$ and $60 \mathrm{kDa}$ subunits of $\mathrm{Ca}^{2+} /$ calmodulin-dependent protein kinase II (CKII), tubulin, B-50, the $\alpha$-subunit of pyruvate dehydrogenase and myelin basic proteins. CKII phosphorylation in situ appeared similar but not identical to its in vitro counterpart. Phosphopeptide mapping analysis of in situ labeled substrate proteins indicated that CAMP-, $\mathrm{Ca}^{2+} / \mathrm{cal}-$ modulin-, and $\mathrm{Ca}^{2+} /$ phospholipid-dependent protein kinases were all active in slice preparations under basal conditions. Increased ${ }^{32} \mathrm{P}_{i}$ labeling of hippocampal proteins following tissue depolarization appeared to be associated with increased activity of endogenous protein kinases since depolarization did not result in ${ }^{32} \mathrm{P}_{1}$-labeling of any new phosphoproteins.
\end{abstract}

Protein phosphorylation is thought to play an important role in neuronal function (Nestler and Greengard, 1984; Browning et al., 1985). Increasing evidence suggests that protein phosphorylation is an important mechanism in the transduction of extracellular signals that modulate diverse cellular processes such as metabolism, excitability, neurotransmitter release, and synaptic plasticity (Nestler and Greengard, 1984; Melchers et al., 1988).

Two major classes of protein kinase have been described in the nervous system and they are the $\mathrm{Ca}^{2+}$ - and cyclic nucleotidedependent protein kinases (Nairn et al., 1985). Previous studies have shown that $\mathrm{Ca}^{2+}$ influx into synaptosomes leads to a $\mathrm{Ca}^{2+}$ dependent phosphorylation of many endogenous proteins (Krueger et al., 1977; Wu et al., 1982; Robinson and Dunkley, 1983a; Wang et al., 1988) and the activation of $\mathrm{Ca}^{2+} /$ calmodu-

\footnotetext{
Received Oct. 28, 1988; revised Mar. 3, 1989; accepted Mar. 24, 1989.

This work was supported by Public Health Service Grant NS22452 to P.T.K Correspondence should be addressed to Paul T. Kelly at the above address.

a Present address: Department of Physiology, University of Maryland School of Medicine, Baltimore, MD 21201.

Copyright (C) 1989 Society for Neuroscience $0270-6474 / 89 / 103618-13 \$ 02.00 / 0$
}

lin-, $\mathrm{Ca}^{2+} /$ phospholipid-dependent protein kinases and protein phosphatases (Dunkley et al., 1986; Robinson ct al., 1987; Wang et al., 1988). $\mathrm{Ca}^{2+}$ influx also activates adenyl cyclase (Brostrom et al., 1975; Cheung et al., 1975), leading to an increase in intracellular cAMP which could activate cAMP-dependent protein kinase. The majority of studies on protein phosphorylation in the brain have been carried out in vitro by using subcellular fractions or synaptosomes and $\left[\gamma^{32} \mathrm{P}\right]-\mathrm{ATP}$ as phosphate donor. Few studies have been carried out under in situ conditions. The relationship between in situ and in vitro protein phosphorylation is crucial to understanding the physiological significance of protein phosphorylation in neural tissues. In the present studies, we have examined the $\mathrm{Ca}^{2+}$-dependent protein phosphorylation systems under in situ conditions using hippocampal slices. We have investigated the subcellular distribution, activity, and substrates of protein kinases and phosphatases in hippocampal tissue slices. We have studied factors that regulate the in situ state of phosphorylation of hippocampal proteins. We have focused on $\mathrm{Ca}^{2+} /$ calmodulin-dependent protein kinase II (CKII) because of its high concentration in the nervous system (Bennett et al., 1983; Erondu and Kennedy, 1985), synaptic junctions (Kelly and Cotman, 1978), and postsynaptic densities (Kennedy et al., 1983; Goldenring et al., 1984; Kelly et al., 1984), and its proposed role in synaptic transmission (DeLorenzo et al., 1979; Llinás et al., 1985) and synaptic plasticity (Wasterlain and Farber, 1984; Goldenring et al., 1986). We have compared the in situ and in vitro phosphorylation characteristics of CKII and the phosphorylation of endogenous substrate proteins. Our results demonstrated that $\mathrm{Ca}^{2+}$ - and cyclic nucleotide-dependent protein kinases and protein phosphatases were active under basal conditions, and their activities were further stimulated by high$\mathrm{K}^{+}$depolarization. We have identified CKII in all hippocampal subcellular fractions and reported differences between its phosphorylation properties observed in situ and in vitro. A preliminary report of this study has appeared elsewhere (Yip and Kelly, 1986).

\section{Materials and Methods}

In situ phosphorylation of hippocampal slices. Sprague-Dawley male rats (100-174 gm) were decapitated and hippocampi placed in oxygenated low-phosphate Krebs Ringer bicarbonate buffer (KRB, pH 7.3) containing (in mM) NaCl, 124.0; KCl, 5.0; $\mathrm{NaHCO}_{3}, 25.0 ; \mathrm{Na}_{2} \mathrm{HPO}_{4}, 0.075$; $\mathrm{MgSO}_{4}, 1.5$; and glucose, 10.0 . Tissue slices $(0.30 \times 0.30 \times 2 \mathrm{~mm})$ were prepared with a Mcllwain tissue chopper, washed twice with $K R B$, and placed in $\mathrm{KRB}$ containing either $1 \mathrm{mM} \mathrm{CaCl}{ }_{2}$ or $1 \mathrm{~mm}$ EGTA. Slices were equilibrated at $37^{\circ} \mathrm{C}$ for $30 \mathrm{~min}$ in a covered shaking water bath in $95 \% \mathrm{O}_{2} / 5 \% \mathrm{CO}_{2}$. Slices were then prelabeled with ${ }^{32} \mathrm{P}$-orthophosphate $(1.5 \mathrm{mCi} / \mathrm{ml}$; New England Nuclear) for $45 \mathrm{~min}$ under the same conditions. After ${ }^{32} \mathrm{P}_{\mathrm{i}}$ prelabeling, some slices in $\mathrm{KRB}$ plus $\mathrm{Ca}^{2+}$ were incubated an additional $5 \mathrm{~min}$ in onc of the following agents (final concentration in mM): verapamil, 0.5; D-600, 0.25 (Knoll Pharmaceutical Co.); $\mathrm{MnCl}_{2}, 25.0 ; \mathrm{CoCl}_{2}, 25.0$; or EGTA, 1.0. Twenty minutes prior to high-K+ depolarization, W-13 (0.3 mM; Seikagaku America Inc.) was added to one group of slices in KRB plus $\mathrm{Ca}^{2+}$. Certain slices were then 
depolarized in high- $\mathrm{K}^{+} \mathrm{KRB}$ media $(57.5 \mathrm{~mm} \mathrm{KCl}$, final concentration) for $1 \mathrm{~min}$. The tonicity of the high- $\mathrm{K}^{+} \mathrm{KRB}$ media was maintained by decreasing the $\mathrm{NaCl}$ concentration accordingly. Control slices were incubated in either $\mathrm{KRB}$ plus $\mathrm{Ca}^{2+}$ or KRB plus EGTA for $50 \mathrm{~min}$. Slices were then depolarized for $1 \mathrm{~min}$ with high- $\mathrm{K}^{+} \mathrm{KRB}$ in the presence of either $\mathrm{Ca}^{2+}$ or EGTA.

The duration of ${ }^{32} \mathrm{P}_{\mathrm{i}}$ prelabeling was examined for its effects on protein phosphorylation in $\mathrm{CaCl}_{2}$-containing versus $\mathrm{Ca}^{2+}$-free media. The overall patterns and degree of protein labeling in different subcellular fractions changed very little between 45 and $70 \mathrm{~min}$ of prelabeling (1dimensional gel analysis). Prelabeling periods of $85-100$ min resulted in overall decreases in protein phosphorylation and suggested a decline in the specific activity of ${ }^{32} \mathrm{P}$-ATP pools and/or viability of tissue slices. Thus, the $45 \mathrm{~min}$ prelabeling periods used in these experiments appeared to represent a time at which protein phosphorylation had reached steadystate levels.

Identical amounts of $i$ situ labeled proteins from different subcellular fractions were analyzed by 1 - and 2-dimensional gel electrophoresis and autoradiography with intensifying screens (Dupont). Multiple exposures of each gel were performed to obtain autoradiographic images of individual proteins that ranged in intensity by 1 - to 4 -fold and to ensure that exposures were approximately linear with respect to silver grain development. Only changes in the phosphorylation of a given protein, which differed more than 2 -fold between any 2 experimental conditions, have been described.

Analyses of in situ protein phosphorylation comprised a total of 11 independent experiments. Within each experiment, individual ${ }^{32} \mathrm{P}_{\mathrm{i}}$-labeling conditions were carried out in duplicate; a minimum of 22 independently isolated subcellular fractions were analyzed by both 1 - and 2-dimensional gel electrophoresis for each labeling condition. Experiments employing $\mathrm{Ca}^{2+}$-channel blockers and $\mathrm{W} 13$ were examined in duplicate in 2 separate experiments and analyzed on 1-dimensional gels. Our results describe changes in protein phosphorylation patterns that were observed in at least 9 out of 11 experiments.

Subcellular fractionation. All procedures were done at $4^{\circ} \mathrm{C}$. Following experimental treatments, slices were quickly rinsed 3 times with KRB plus $\mathrm{Ca}^{2+}$ containing $20 \mathrm{~mm} \mathrm{NaF}, 1 \mathrm{~mm}$ EDTA, $0.1 \mathrm{~mm}$ phenylmethylsulfonyl fluoride (PMSF), $2 \mu \mathrm{g} / \mathrm{ml}$ leupeptin, and $5 \mu \mathrm{g} / \mathrm{ml}$ soybean trypsin inhibitor. Slices were homogenized in $800 \mu$ l buffer ( $\mathrm{pH} 7.3$ ) containing $2 \mathrm{~mm}$ Tris- $\mathrm{HCl}, 10 \mathrm{~mm} \mathrm{NaF}, 1 \mathrm{~mm}$ EDTA, $0.1 \mathrm{~mm}$ PMSF, 2 $\mu \mathrm{g} / \mathrm{ml}$ leupeptin, and $5 \mu \mathrm{g} / \mathrm{ml}$ soybean trypsin inhibitor with a Teflonglass homogenizer. Homogenates were centrifuged at $16,000 \times g$ for 10 min. The resulting supernatants (cytosolic or $\mathrm{S} 1$ fractions) were collected and pellets were resuspended in $200 \mu \mathrm{l}$ of $2 \mathrm{~mm}$ Hepes (pH 7.2) and centrifuged at $11,000 \times g$ for $10 \mathrm{~min}$. The resulting supernatants were discarded, and the crude particulate fractions were resuspended in 350 $\mu$ l of $0.32 \mathrm{~m}$ sucrose $(0.5 \mathrm{~mm}$ Hepes, $\mathrm{pH} 7.3)$ and centrifuged at $450 \times$ $g$ for $8 \mathrm{~min}$ to remove nuclei and cell debris. Crude nuclear pellets were discarded and $1 / 10$ th volume of $4 \%$ Triton X-100 was added to the remaining synaptosomal/mitochondrial suspension. Triton X-100/particulate suspensions were incubated for $15 \mathrm{~min}$ and centrifuged at 16,000 $\times g$ for $15 \mathrm{~min}$. The resulting Triton soluble (TXs) fractions were collected and Triton-insoluble (TXi) pellets were resuspended in $200 \mu \mathrm{l}$ of $2 \mathrm{~mm}$ Hepes ( $\mathrm{pH} 7.2$ ). Protein concentrations were determined by the method of Lowry et al. (1951). Subcellular fractions were stored at $-80^{\circ} \mathrm{C}$.

Phosphorylation of synaptic junction (SJ) proteins and purified cytosolic CKII. Preparation of SJ fractions and purified cytosolic CKII was carried out as previously described (Kelly et al., 1987). SJ fractions (20 $\mu \mathrm{g})$ and purified cytosolic CKII $(0.04-2 \mu \mathrm{g})$ were phosphorylated in vitro as outlined previously (Kelly et al., 1984). For comigration experiments, $2 \mu \mathrm{g}$ purified CKII were phosphorylated with unlabeled ATP and added to in situ ${ }^{32} \mathbf{P}_{\mathrm{i}}$-labeled hippocampal proteins prior to electrophoretic analyses.

Back-phosphorylation of hippocampal proteins. In situ phosphorylation of hippocampal proteins was carried out in KRB containing 1.5 $\mathrm{mM} \mathrm{Na}_{2} \mathrm{HPO}_{4}$ and no ${ }^{32} \mathrm{P}_{\mathrm{i}}$ under conditions outlined above. Back-phosphorylation was performed using the in vitro protocol described by Kelly et al. (1984). Subcellular fractions ( $10 \mu \mathrm{g}$ protein) were phosphorylated in buffer containing EGTA ( $2 \mathrm{~mm}$ ) or $\mathrm{CaCl}_{2}(1 \mathrm{~mm})$ plus calmodulin (20 $\mu \mathrm{g} / \mathrm{ml})$. Phosphorylation was initiated by the addition of $5 \mu \mathrm{Ci}\left[\gamma^{\left.-{ }^{32} \mathrm{P}\right]}\right.$ ATP (15 $\mu \mathrm{M}$ final concentration) and shifting reactions to $30^{\circ} \mathrm{C}$ for 30 sec. Reactions were terminated by the addition of 4 X-SDS sample buffer.

Gel electrophoresis and peptide mapping. Subcellular fractions were analyzed by 1-dimensional SDS-PAGE as described by Laemmli (1970) or by 2-dimensional gel electrophoresis (O'Farrell, 1975) as modified by Kelly et al. (1985). Molecular-weight standards (14-92 kDa; BioRad) were included in each gel. One-dimensional peptide mapping was carried out as described by Cleveland et al. (1977) using $S$. aureus V8 protease ( $2.5 \mu \mathrm{g} /$ gel slice; Miles) and analyzed on $12-20 \%$ gradient gels.

Immunoblotting. Proteins were transferred to nitrocellulose as described by Towbin and Gordon (1984). Nitrocellulose transfers (immunoblots) were incubated $4 \mathrm{hr}$ at $45^{\circ} \mathrm{C}$ in Tris-buffered saline [TBST $10 \mathrm{~mm}$ Tris- $\mathrm{HCl}, \mathrm{pH} 8.0,150 \mathrm{mM} \mathrm{NaCl}$, and $0.05 \%(\mathrm{vol} / \mathrm{vol})$ Tween 20 ] containing $10 \%$ BSA. Blots were incubated overnight at $4^{\circ} \mathrm{C}$ in TBST containing $0.5 \%$ BSA plus polyclonal antibodies against CKII (1:50-1: 100 final dilution). CKII antiserum has been previously described by Kelly et al. (1987). Control immunoblots were incubated with preimmune serum at the samc dilutions. Blots were washed in TBST containing $2 \% \mathrm{BSA}$ and incubated $\left(1 \mathrm{hr} / 25^{\circ} \mathrm{C}\right)$ in alkaline phosphataseconjugated secondary antibody (1:7500; goat anti-rabbit, Organon Teknika). After 5 washes, immunoreactive bands were visualized with nitroblue tetrazolium and 5-bromo-4-chloro-3-indoyl phosphate (Promega).

Immunoprecipitation. ${ }^{32} \mathrm{P}_{-}$-labeled proteins $(6-24 \mu \mathrm{g})$ were solubilized in buffer A containing (in mM): Tris- $\mathrm{HCl}, \mathrm{pH} 7.0,20.0$; EDTA, 5.0; dithiothreitol, 1.0; PMSF, 1.0; and $1 \%$ (wt/vol) SDS at $80^{\circ} \mathrm{C}$ for $5 \mathrm{~min}$. SDS-solubilized samples were diluted $(1: 10)$ with buffer $B$ containing (in mM): Tris-HCl, pH 7.0, 10.0; EDTA, 5.0; PMSF, 1.0; NaF, 150.0; and $0.25 \%$ (vol/vol) Nonidet P-40 (NP-40). Samples were incubated with CKII antiserum (1:50-1:100 final dilution) overnight at $4^{\circ} \mathrm{C}$. Controls were incubated with preimmune serum. Immune complexes were precipitated with $50 \mu \mathrm{l}$ Pansorbin (10\% suspension, Calbiochem) after incubation for $1^{1 / 2} \mathrm{hr}$ at $4^{\circ} \mathrm{C}$. Pansorbin-immune complexes were collected by centrifugation $(10,000 \times \mathrm{g}, 10 \mathrm{~min})$, washed 5 times in buffer $\mathrm{C}(150 \mathrm{~mm} \mathrm{NaCl}, 15 \mathrm{~mm}$ Tris, and $0.25 \% \mathrm{NP}-40)$, solubilized in SDSsample buffer, and analyzed on 1-dimensional gels.

\section{Results}

\section{Conditions for in situ phosphorylation}

Effects of calcium. Representative patterns of phosphorylated proteins in various subcellular fractions after in situ labeling of hippocampal tissue slices are shown in Figure 1 (Fig. I, $A-C$, lanes 2-5). Compared with low-phosphate ( $75 \mu \mathrm{M}) \mathrm{Krebs}$-Ringer buffer, inclusion of $1.5 \mathrm{~mm}$ phosphate in Krebs-Ringer buffer during slice equilibration and prelabeling significantly decreased the overall incorporation of ${ }^{32} \mathrm{P}_{\mathrm{i}}$ into individual proteins in different slice fractions (results not shown). Subsequent equilibration and prelabeling conditions employed buffers that were low in phosphate $(75 \mu \mathrm{M})$. To examine conditions for maximum in situ phosphorylation of hippocampal proteins, the effects of $\mathrm{Ca}^{2+}$ on ${ }^{32} \mathrm{P}_{\mathrm{i}}$ incorporation was examined during slice equilibration and prelabeling periods. Under basal conditions, chelation of exogenous $\mathrm{Ca}^{2+}$ with $1 \mathrm{~mm}$ EGT $\Lambda$ during equilibration and prelabeling caused uniform reductions in protein phosphorylation (Fig. 1, $A-C$, lane 2). Inclusion of $1 \mathrm{mM} \mathrm{CaCl}_{2}$ in equilibration and prelabeling buffers markedly stimulated ${ }^{32} \mathrm{P}_{i}$-incorporation into proteins in all subcellular fractions (Fig. 1, $A-C$, lane 4). The stimulatory effect of $\mathrm{Ca}^{2+}$ was prominent in cytosolic fractions where $\mathrm{Ca}^{2+}$ significantly increased the phosphorylation of $93,80,48,45,19$, and $14 \mathrm{kDa}$ proteins compared with EGTA/ basal conditions (Fig. $1 A$, lane 4 vs 2 ). In particulate-derived fractions, the presence of $\mathrm{Ca}^{2+}$ during equilibration and prelabeling stimulated the phosphorylation of many proteins compared with EGTA/basal conditions, particularly 150, 130, 93, $66,64,60,50,45$, and $14 \mathrm{kDa}$ phosphoproteins in TXs (Fig. $1 B$, lane 4 vs 2 ), and $51,42,40,38$, and $14 \mathrm{kDa}$ phosphoproteins in TXi fractions (Fig. 1C, lane 4 vs 2). The phosphorylation of the $93 \mathrm{kDa}$ in cytosolic and $60-66 \mathrm{kDa}$ proteins in TXs fractions appeared to be $\mathrm{Ca}^{2+}$ dependent.

Effects of high- $\mathrm{K}^{+}$depolarization. In the presence of exogenous 
A. CYTOSOLIC

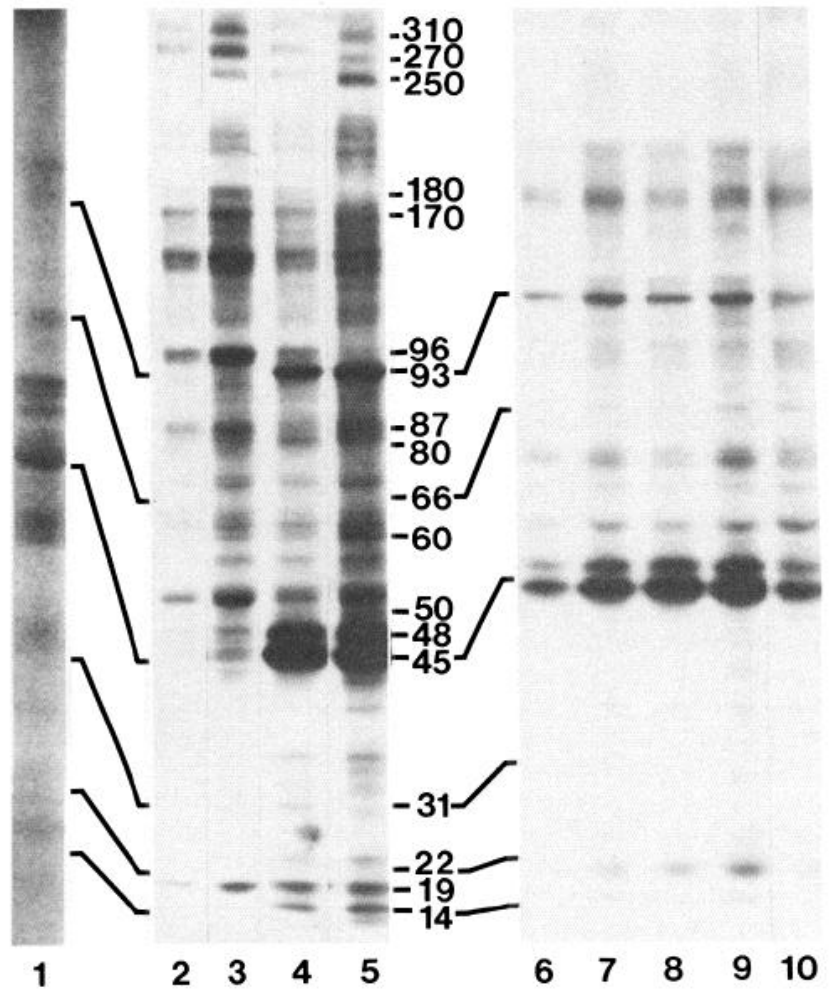

C. TRITON X-100 INSOLUBLE

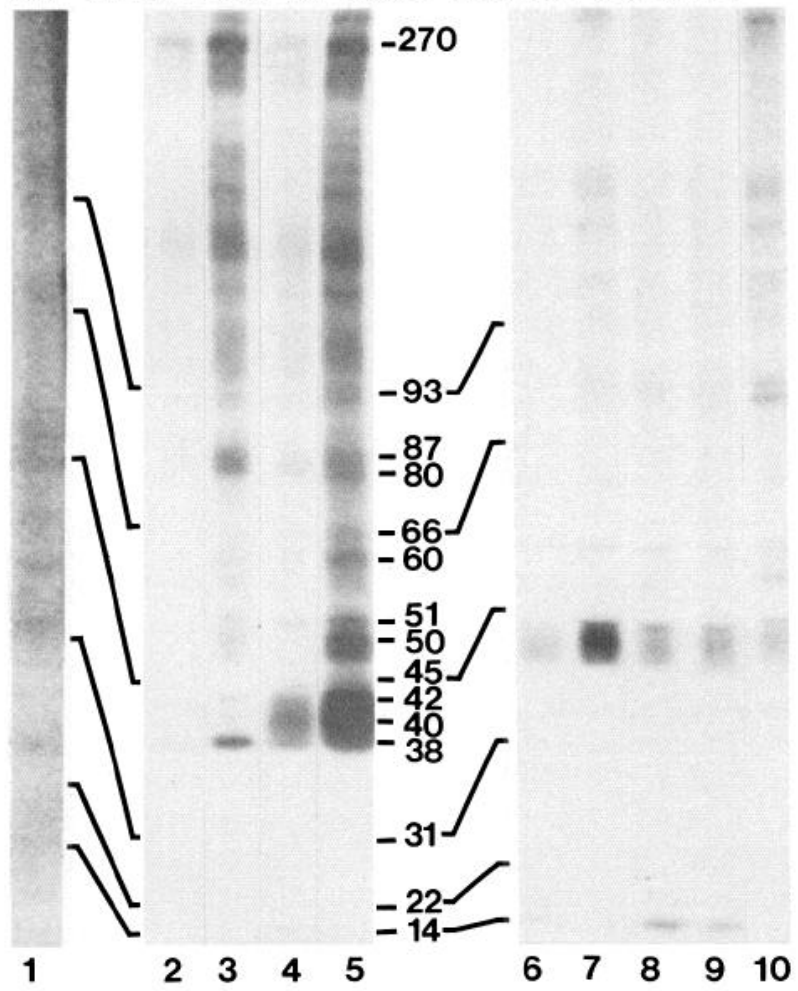

B. TRITON X-100 SOLUBLE

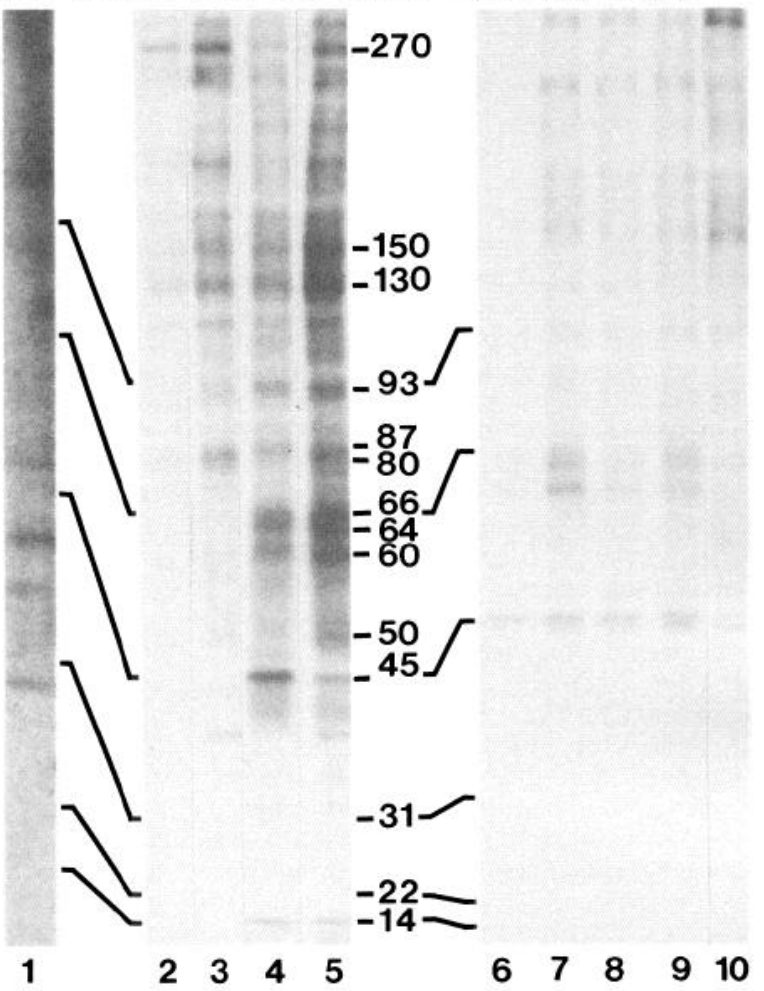

Figure 1. Autoradiograms of in situ ${ }^{32} \mathrm{P}$-incorporation into hippocampal proteins in different subcellular fractions: $A$, cytosolic; $B$, Triton $\mathrm{X}-100$ soluble; and $C$, Triton X-100 insoluble. Slices were prelabeled for $45 \mathrm{~min}$ with ${ }^{32} \mathrm{P}$ in buffer containing either $1 \mathrm{~mm} \mathrm{CaCl}_{2}($ lanes $4-10)$ or $1 \mathrm{~mm}$ EGTA (lanes 2 and 3). Slices were then incubated for $1 \mathrm{~min}$ in either control (lanes 2 and 4 ) or high- $\mathrm{K}^{+}$buffer (lanes 3 and $5-10$ ) containing the same concentration of either $\mathrm{CaCl}_{2}$ (lanes 4-10) or EGTA (lanes 2 and 3). $\mathrm{Ca}^{2+}$-channel blockers, 0.5 mM verapamil (lane 6), 0.25 mM D-600 (lane 7), $25 \mathrm{mM} \mathrm{MnCl}_{2}$ (lane 8), or $25 \mathrm{mM} \mathrm{CoCl}_{2}$ (lane 9) were added $5 \mathrm{~min}$ before depolarization, or the calmodulin antagonist W-13 (0.3 mM, lane 10) was added 20 min before depolarization. Lane 1 contains hippocampal proteins phosphorylated under in situ conditions in the absence of ${ }^{32} \mathrm{P}_{\mathrm{i}}$, 
$\mathrm{Ca}^{2+}(1 \mathrm{mM})$, high- $\mathrm{K}^{+}$depolarization rcsultcd in an ovcrall increase of ${ }^{32} \mathrm{P}_{\mathrm{i}}$ incorporation into slice proteins in all subcellular fractions compared with $\mathrm{Ca}^{2+} /$ basal conditions (Fig. l, $A-C$, lane 5 vs 4 ). In the cytosolic fractions, high- $\mathrm{K}^{+}$depolarization in $\mathrm{Ca}^{2+}$ increased the phosphorylation of $310,250,93,87-80,60,50$, 48 , and $45 \mathrm{kDa}$ proteins about 2- to 3-fold over $\mathrm{Ca}^{2+} /$ basal conditions (Fig. $1 A$, lane 5 vs 4 ). In contrast, several phosphoproteins underwent dephosphorylation following high- $\mathrm{K}^{1 / \mathrm{Ca}^{21}}$ depolarization compared with high $\mathrm{K}^{+} /$EGTA and displayed $M_{r}$ 's of $310,270,180,170$, and $96 \mathrm{kDa}$ (Fig. $1 A$, lane 5 vs 3 ). In TXs fractions, high- $\mathrm{K}^{+}$depolarization in $\mathrm{Ca}^{2+}$ increased the phosphorylation of $270,150,130,87-80,66,64,60$, and 50 $\mathrm{kDa}$ proteins by approximately 3 -fold, while the $45 \mathrm{kDa}$ protein was dephosphorylated about 3-fold compared with $\mathrm{Ca}^{2+} /$ basal conditions (Fig. $1 B$, lane 5 vs 4). In TXi fractions, depolarization in $\mathrm{Ca}^{2+}$ increased basal phosphorylation of 270, 87-80, 60, 51, 50 , and $42-38 \mathrm{kDa}$ proteins by about 3- to 4 -fold (Fig. $1 C$, lane 5 vs 4). High- $\mathrm{K}^{+}$depolarization in EGTA caused a uniform increase in the phosphorylation of hippocampal proteins in slices that were equilibrated and prelabeled in buffers containing EGTA compared with EGTA/basal conditions (Fig. $1, A-C$, lane 3 vs 2).

$\mathrm{Ca}^{2+}$-stimulated phosphorylation. As described above, the presence of exogenous $\mathrm{Ca}^{2+}$ during equilibration and prelabeling markedly increased the phosphorylation of many hippocampal proteins (Fig. 1, $A-C$, lanes 2 vs 4). The latter appeared specific since the addition of $\mathrm{Ca}^{2+}$-channel blockers or the calmodulin antagonist $\mathrm{W}-13,5$ and 20 min prior to high $\mathrm{K}^{+}$-depolarization in $\mathrm{Ca}^{2+}$, respectively, decreased ${ }^{32} \mathrm{P}_{\mathrm{i}}$-incorporation into hippocampal proteins (Fig. 1, $A-C$, lanes 5 vs 6-10). In general, the organic $\mathrm{Ca}^{2+}$-channel blockers verapamil and D-600 were more effective inhibitors (10- and 3-fold, respectively) of protein phosphorylation in hippocampal slices (Fig. 1, $A-C$, lanes 6 and 7) compared with the inorganic $\mathrm{Ca}^{2+}$-channel blockers $\mathrm{MnCl}_{2}$ and $\mathrm{CoCl}_{2}$ (Fig. 1, $A-C$, lanes 8 and 9). W-13 was approximately equal in potency to verapamil in reducing protein phosphorylation compared with $\mathrm{Ca}^{2+} /$ high $\mathrm{K}^{+}$conditions (Fig. 1, $A-C$, lane 5 vs 10$)$.

Posthomogenization protein phosphorylation. To examine if proteins were phosphorylated after tissue homogenization and during subcellular fractionation, increasing amounts of $\left[\gamma^{-32} \mathrm{P}\right]-$ ATP $(1-20 \mu \mathrm{Ci} / \mathrm{ml})$ were added immediately before homogenization to slices preincubated under in situ conditions. At the highest amount of $\left[\gamma^{-32} \mathrm{P}\right]$-ATP $(20 \mu \mathrm{Ci} / \mathrm{ml})$, levels of posthomogenization phosphorylation were barely detectable in hippocampal fractions. Extended autoradiographic exposures (3-4 weeks) were necessary to detect phosphorylated proteins. The autoradiographic patterns of proteins phosphorylated with ${ }^{32} \mathrm{P}-$ ATP were qualitatively and quantitatively different compared with in situ ${ }^{32} \mathrm{P}_{\mathrm{i}}$-labeled proteins (Fig. 1, $A-C$, lane 1 vs 5). These results demonstrated that posthomogenization phosphorylation of proteins was negligible and did not contribute to the phosphorylation patterns observed from in situ labeling.

Endogenous protein phosphatase activity. To examine protein dephosphorylation that may have occurred during or after ho- mogenization of in situ labeled hippocampal slices, endogenous protein phosphatase activity was examined by SDS-PAGE and autoradiography after homogenates were incubated at $4^{\circ} \mathrm{C}$ for 0,45 , and $90 \mathrm{~min}$. These comparisons revealed no discernible differences in the autoradiographic patterns of phosphoproteins in slice homogenates following prolonged in vitro incubations (results not shown). Since tissue homogenization was completed within 3-5 min after in situ labeling, and the initial stages of subcellular fractionation were carried out in phosphatase inhibitors (i.e., NaF and EDTA), the absence of detectable endogenous phosphatase activity was not surprising. Additional experiments in which ${ }^{32} \mathrm{P}$-phosphorylase $a$ (a substrate for protein phosphatase type- 1 and $-2 A$ ) was added to different subcellular fractions showed very little, if any, protein phosphatase activity under the conditions used to fractionate in situ labeled slices (data not shown).

Two-dimensional analysis of phosphoproteins. Because of the limited resolution of 1-dimensional gels, in situ phosphorylated proteins were analyzed on 2-dimensional gels. As observed in 1-dimensional gels, the phosphorylation of many cytosolic proteins increased when $\mathrm{Ca}^{2+}$ was present during equilibration and prelabeling and was further stimulated by high $-\mathrm{K}^{+}$depolarization (Fig. $2, B-D$ ). These phosphoproteins displayed $M_{r}$ 's of 200, 150, 110,96a, 93a, 93b, 87, 60, and 50 (subunits of CKII, see below), 53, 38, 37, 35, 34, 33, 28a, 28b, 25, 24a, 24b, 24c, 22a, 22b, 14a, and 14b kDa (Fig. 2C). Many cytosolic phosphoproteins exhibited isoelectric microheterogeneity and included $87,48,46,45,33,28,24,18$, and $14 \mathrm{kDa}$ proteins.

Exogenous $\mathrm{Ca}^{2+}$ also led to dephosphorylation of several cytosolic proteins of $250,130,120 \mathrm{a}, 120 \mathrm{~b}, 115,95,91,88$, synapsin I, 55, and $28 \mathrm{c} \mathrm{kDa} \mathrm{(Fig.} \mathrm{2,} C$ vs $D$ ). High- $\mathrm{K}^{+}$depolarization in $\mathrm{Ca}^{2+}$ caused nearly complete dephosphorylation of two 96 $\mathrm{kDa}$ proteins ( $96 \mathrm{~b}$ and $96 \mathrm{c}$ ). On the other hand, $96 \mathrm{~b}$ and $96 \mathrm{c}$ were not dephosphorylated in slices equilibrated and prelabeled in EGTA following high $\mathrm{K}^{+}$depolarization in the absence of exogenous $\mathrm{Ca}^{2+}$. However, when slices subjected to the same conditions were depolarized in the presence of $\mathrm{Ca}^{2+}$, almost complete dephosphorylation of $96 \mathrm{~b}$ and $96 \mathrm{c}$ was observed (results not shown). Thus, dephosphorylation of $96 \mathrm{~b}$ and $96 \mathrm{c}$ was regulated by both $\mathrm{Ca}^{2+}$ and depolarization (Fig. 2, B-D). High- $\mathrm{K}^{+}$ depolarization in EGTA increased the level of phosphorylation of many cytosolic proteins compared with EGTA/basal or $\mathrm{Ca}^{2+} /$ high- $\mathrm{K}^{+}$conditions. These phosphoproteins had molecular weights of $250,130,120 \mathrm{a}, 120 \mathrm{~b}, 115,96 \mathrm{~b}, 96 \mathrm{c}, 88$, synapsin I, 55 , and $46 \mathrm{kDa}$ (Fig. $2 \mathrm{D}$ ). Proteins whose phosphorylation was unaffected by either $\mathrm{Ca}^{2+}$ or EGTA and were stimulated by high-K' depolarization included 105 and $99 \mathrm{kDa}$ polypeptides (Fig. 2, $B-D$ ). Phosphoproteins detected only in cytosolic fractions displayed $M_{r}$ 's of $200,35,28 \mathrm{a}, 28 \mathrm{~b}, 28 \mathrm{c}$, and $18 \mathrm{kDa}$. Phosphoproteins of $150,96,95,93,91,87,53,38,37,35,34$, $33,28,25,24,22,18$, and $14 \mathrm{kDa}$ were detected mainly in the cytosolic fractions.

Fewer phosphoproteins were detected in TXs fractions compared with cytosolic fractions. In TXs fractions, the phosphorylation of $96 \mathrm{a}, 87,55$, and $53 \mathrm{kDa}$ proteins was significantly 

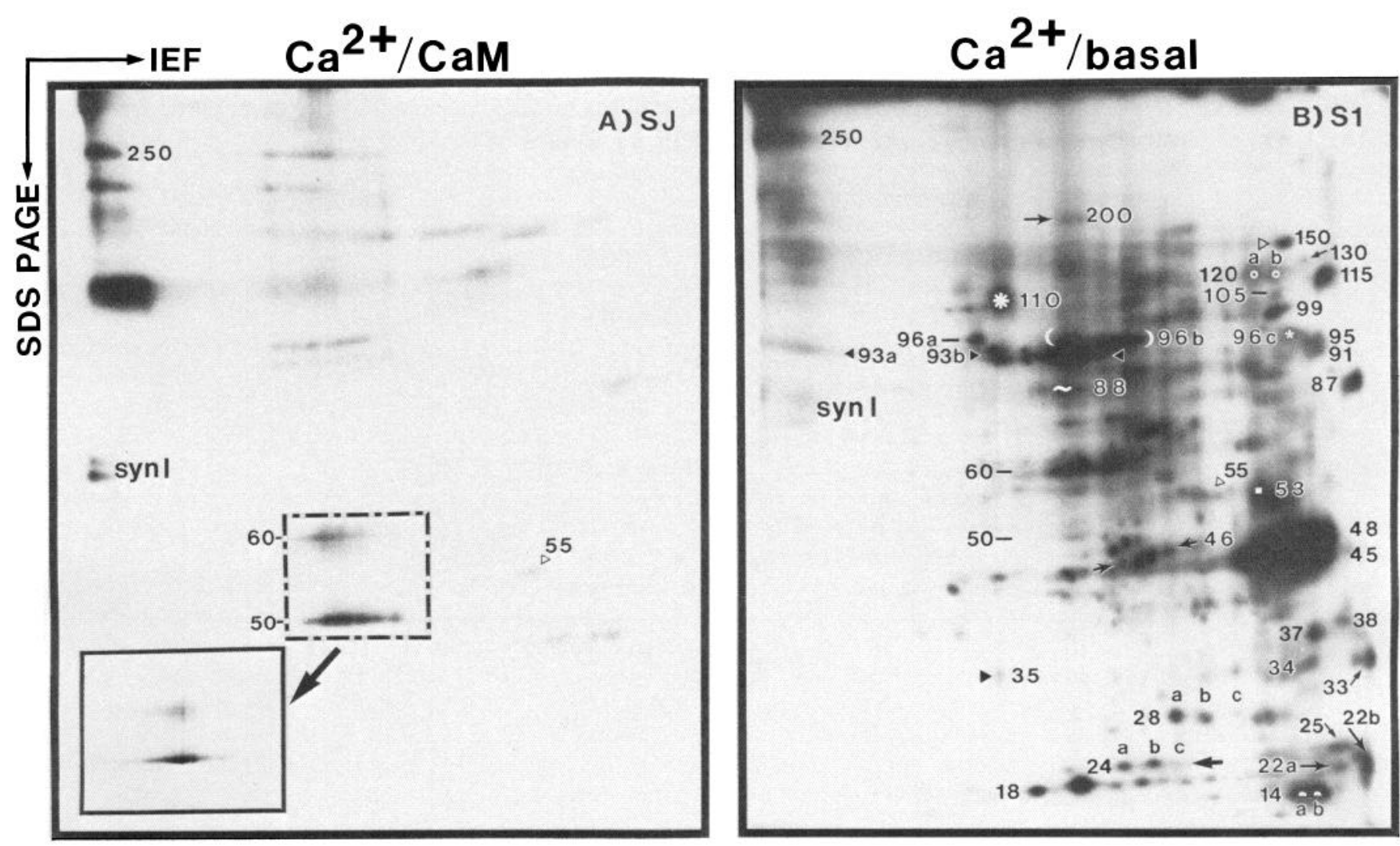

\section{$\mathrm{Ca}^{2+} /$ high K$^{+}$}

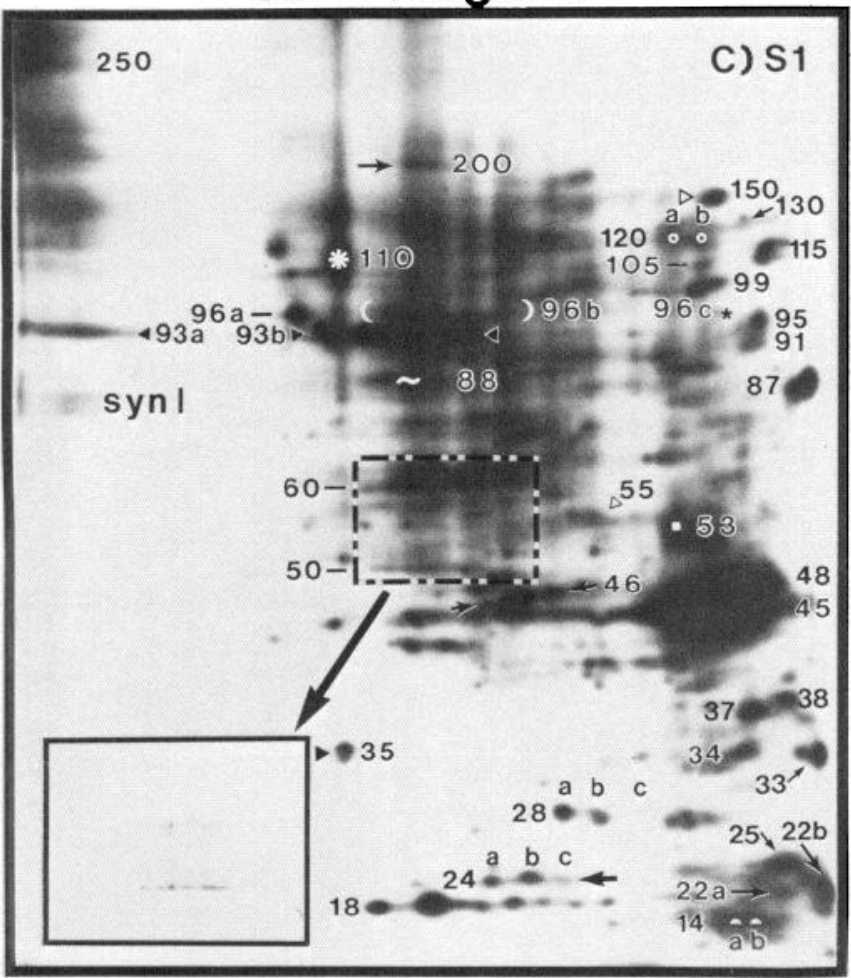

\section{EGTA/high $\mathrm{K}^{+}$}

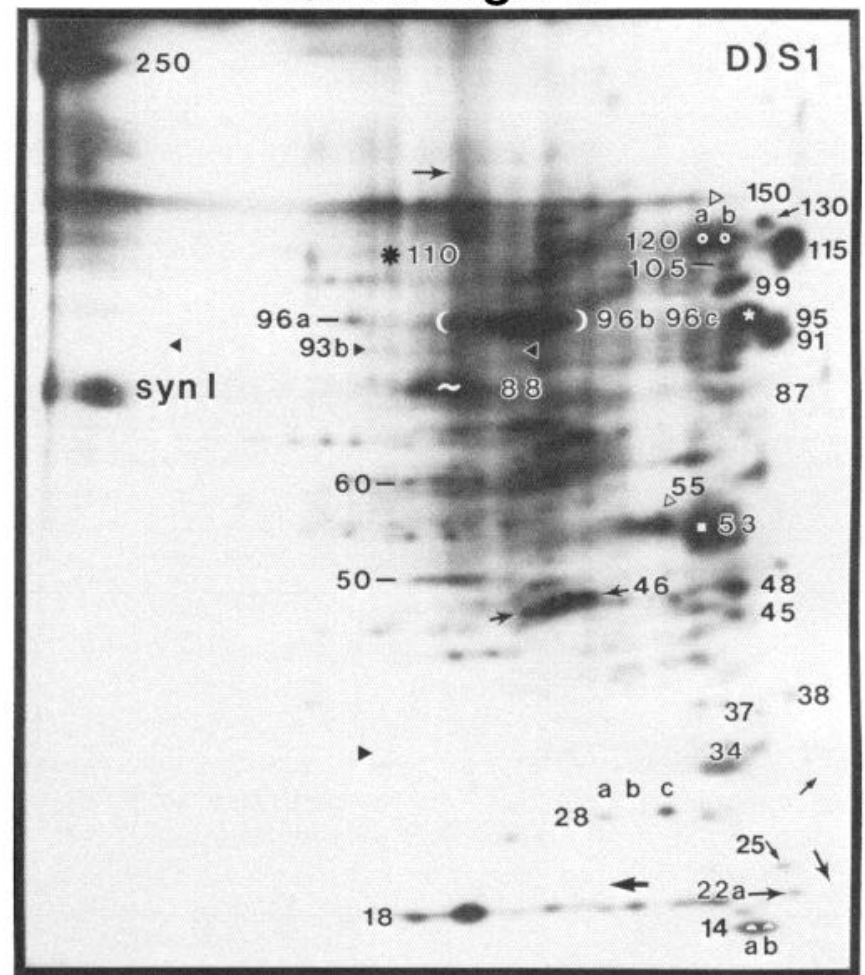

Figure 2. Two-dimensional autoradiograms of synaptic junction $(S J)$ and hippocampal slice proteins phosphorylated in vitro and in situ, respectively. Phosphoproteins are designated by their apparent molecular weights in kilodaltons; $25 \mu \mathrm{g}$ protein was analyzed in each gel. The 50 and 60 $\mathrm{kDa}$ subunits of CKII are labeled accordingly in purified SJ $(A), \mathrm{S} 1(B-D)$, TXs $(E, F)$, and TXi $(G, H)$ fractions. Insets (in $A, C$, $E$, and $G)$ represent the corresponding 2-dimensional immunoblot of CKII subunits. Indicated above each panel is the corresponding in vitro $(A)$ or in situ $(B-H)$ 

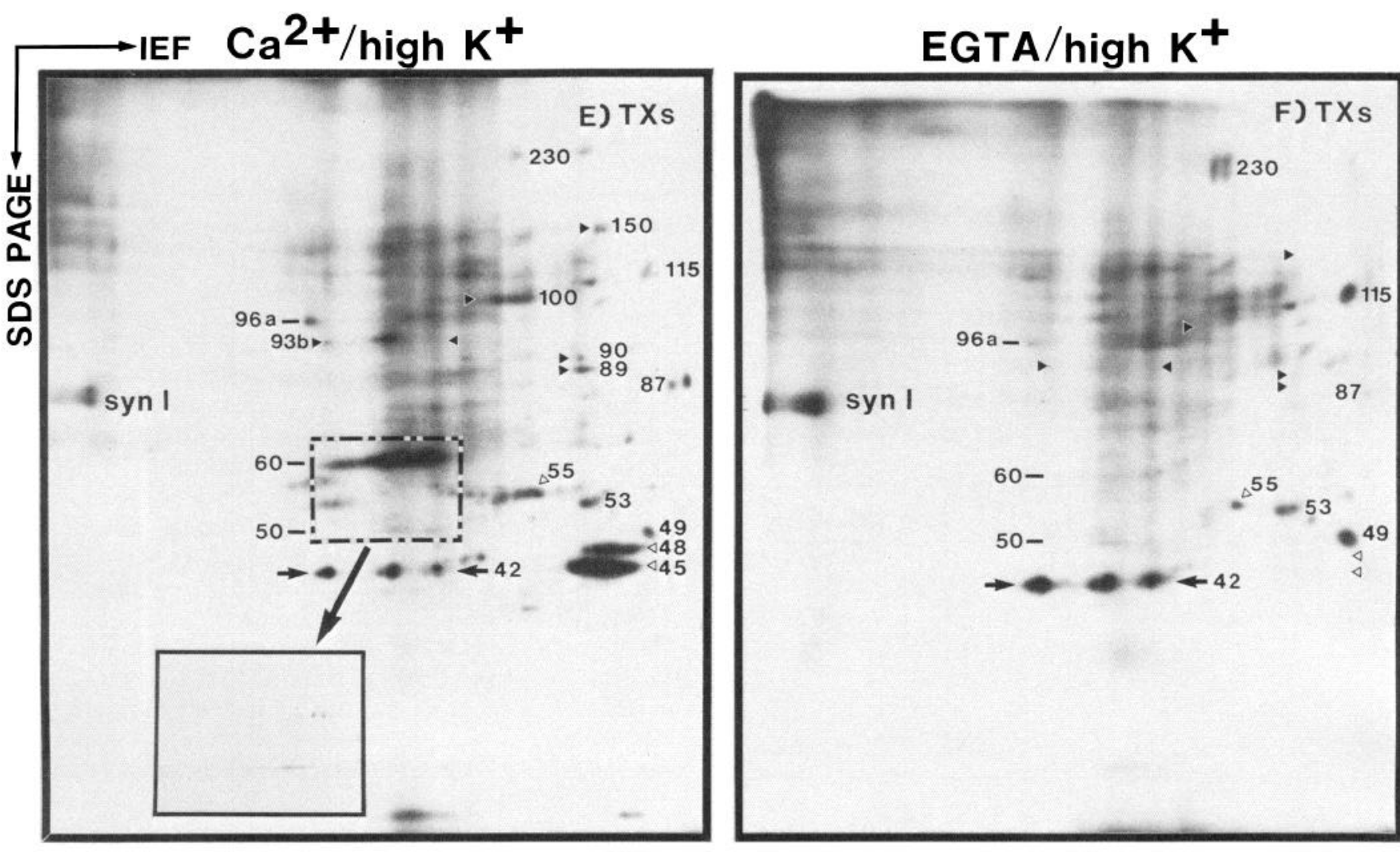

\section{$\mathrm{Ca}^{2+} /$ high K$^{+}$}

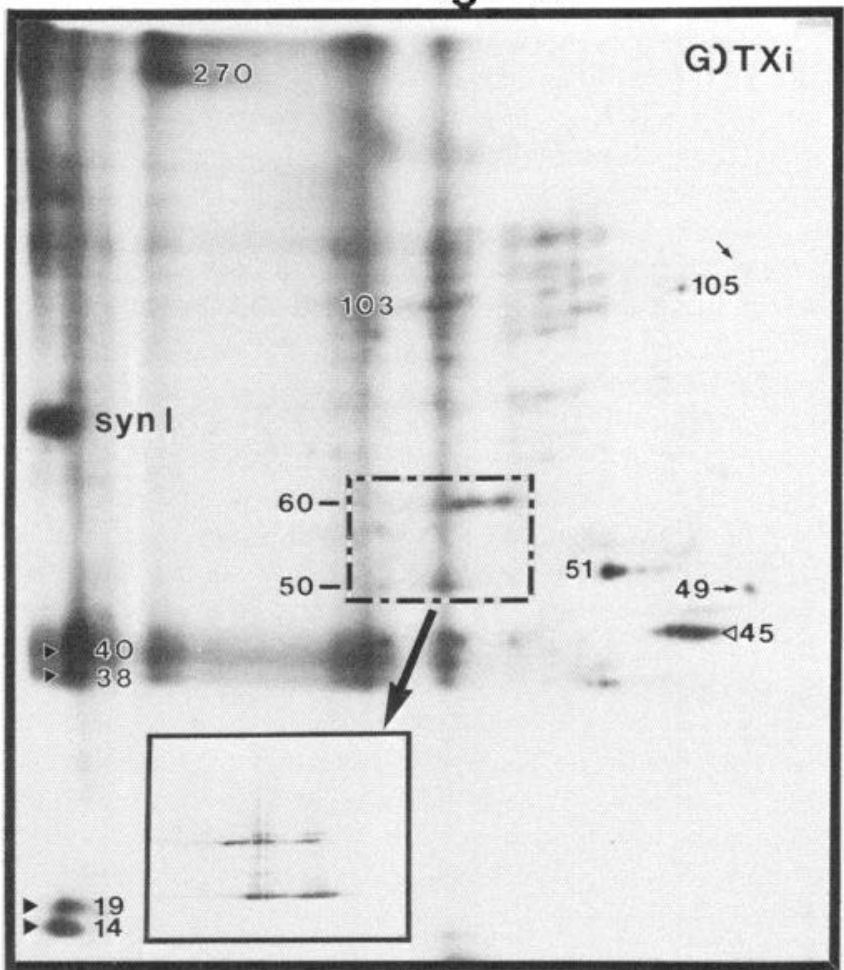

\section{EGTA/high $\mathrm{K}^{+}$}

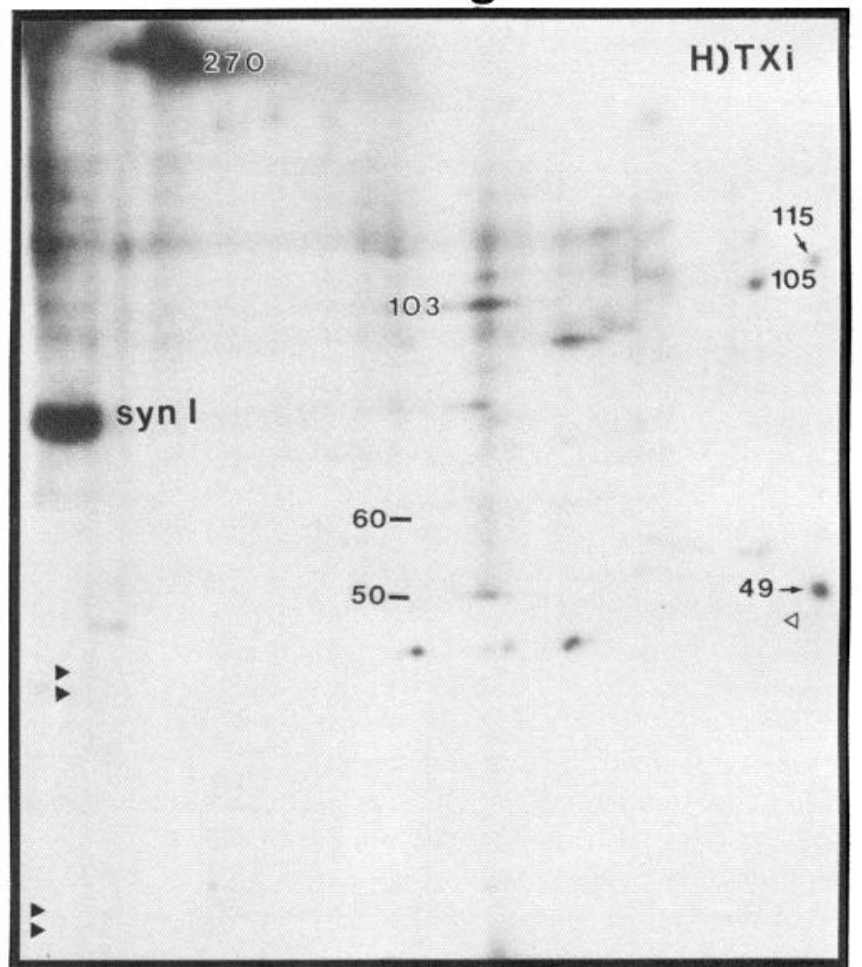

condition used for the analysis of phosphoproteins: $A$, SJ fraction phosphorylated in vitro with $\left[\gamma-{ }^{32} \mathrm{P}\right]-\mathrm{ATP}$ in the presence of $\mathrm{Ca}^{2+}$ and calmodulin $\left(\mathrm{Ca}^{2+} / \mathrm{CaM}\right) ; B-H$, hippocampal slice fractions labeled in situ with ${ }^{32} \mathrm{P}_{i}$ in $\mathrm{Ca}^{2+}$ or EGTA under nondepolarized (basal) or depolarized (high- $\mathrm{K}^{+}$) conditions. Autoradiographic exposures were $7 \mathrm{hr}(A)$ and $7 \mathrm{~d}(B-H)$. 

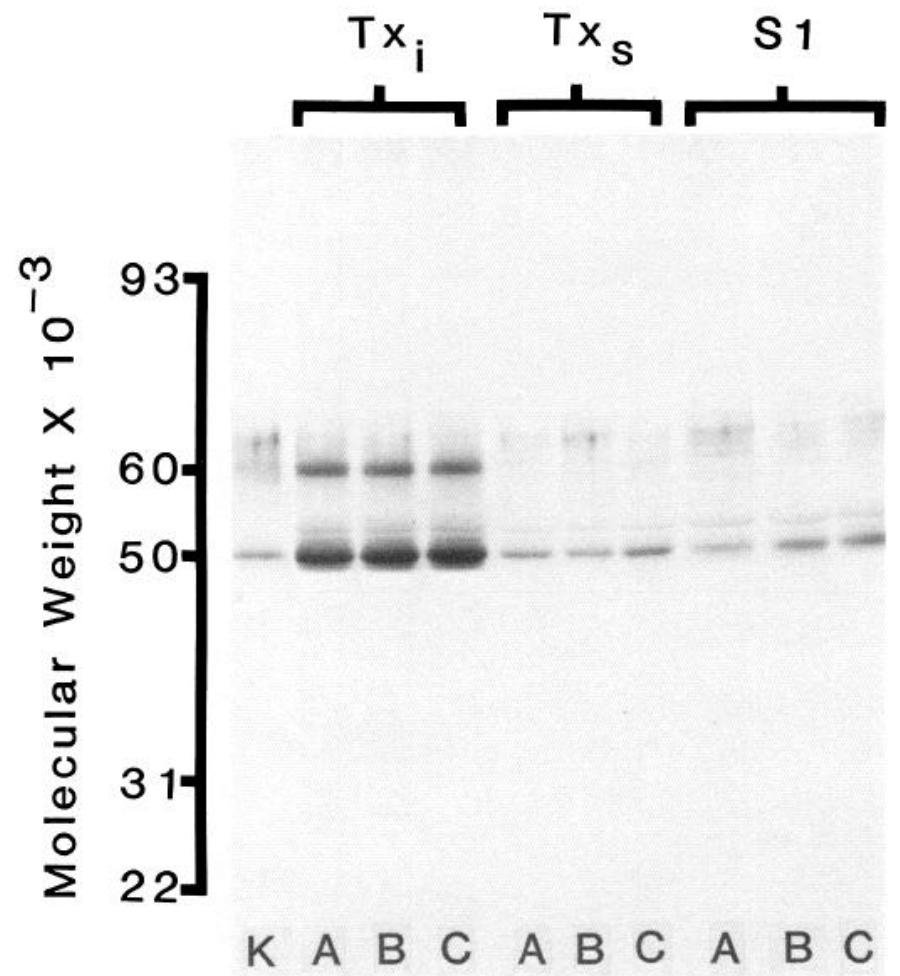

Figure 3. Immunoblot analysis of CKII in different hippocampal fractions. Nitrocellulose transfers of subcellular fractions (S1, TXs, and TXi) separated by SDS-PAGE were incubated with anti-CKII antisera specific for both 50 and $60 \mathrm{kDa}$ subunits, followed by alkaline phosphataseconjugated secondary antibodies. Lanes designated $A$ show 50 and 58/ $60 \mathrm{kDa}$ subunits from slices incubated under $\mathrm{Ca}^{2+} / \mathrm{basal}$ conditions. Lanes designated $B$ show 50 and $58 / 60 \mathrm{kDa}$ subunits from slices incubated under $\mathrm{Ca}^{2+} /$ high $\mathrm{K}^{+}$conditions. Lanes designated $C$ show 50 and $58 / 60 \mathrm{kDa}$ subunits from slices incubated under EGTA/high $\mathrm{K}^{+}$ conditions. Lane $K$ shows the 50 and $58 / 60 \mathrm{kDa}$ subunits from purified CKII.

increased in the presence of $\mathrm{Ca}^{2+}$ when compared with EGTA/ basal conditions (results not shown) and was further stimulated by high-K $\mathrm{K}^{+}$depolarization (Fig. $2, E, F$ ). TXs proteins that displayed $\mathrm{Ca}^{2+}$-dependent phosphorylation were $150,100,93 \mathrm{~b}$, $90,89,60$, and 50 (subunits of CKII), 48 and $45 \mathrm{kDa}$ polypeptides (Fig. $2 E$ ). Phosphoproteins that underwent dephosphorylation in the presence of exogenous $\mathrm{Ca}^{2+}$ included 230,115 , synapsin I, 49, and $42 \mathrm{kDa}$ polypeptides (Fig. 2, $E, F$ ). The 49 and $42 \mathrm{kDa}$ proteins were seen mainly in the TXs fraction. The $49 \mathrm{kDa}$ phosphoprotein was identified as B-50 on 2-dimensional immunoblots using anti-B-50 polyclonal antibodies (generous gift from L. Benowitz; results not shown).

Among the different subcellular fractions, TXi fractions displayed the fewest in situ phosphorylated proteins. The phosphorylation of 60 and 50 (subunits of CKII), 51, 45, 40, 38, 19, and $14 \mathrm{kDa}$ proteins was markedly increased in the presence of $\mathrm{Ca}^{2+}$ compared with EGTA/basal conditions (not shown) and was further stimulated by high-K+ $\mathrm{K}^{+}$depolarization (Fig. $2 G$ ). The 40 and $38 \mathrm{kDa}$ phosphoproteins displayed poor isoelectric focusing. Nevertheless, these proteins were phosphorylated in a $\mathrm{Ca}^{2+}$-dependent manner. $\mathrm{Ca}^{2+}$-stimulated dephosphorylation was observed for $270,115,105$, synapsin I, and $49 \mathrm{kDa}$ proteins (Fig. 2, $G$ vs $H$ ). Phosphorylation of a $103 \mathrm{kDa}$ protein seemed to be unaffected by $\mathrm{Ca}^{2+}$ or EGTA. This phosphoprotein, along with 51,40 , and $38 \mathrm{kDa}$ were detected only in TXi fractions. Certain phosphoproteins in TXi fractions displayed 2-dimensional patterns that were indistinguishable from proteins phosphorylated in vitro by endogenous CKII in purified SJ fractions (e.g., synapsin I and CKII; Fig. 2, $A, G$ ).

Identification of phosphorylated CKII. The presence of the 50 and $60 \mathrm{kDa}$ subunits of CKII in various hippocampal fractions was confirmed by immunoblots using polyclonal antibodies specific for both subunits. The relative levels of both CKII subunits in hippocampal fractions were TXi $\gg$ TXs $\approx$ cytosolic (Fig. 3). Immunoblots also revealed the more phosphorylated form of the $50 \mathrm{kDa}$ subunit of CKII; the latter was visualized as a 54 $\mathrm{kDa}$ immunoreactive band in all fractions. The relative ratios of 50:60 kDa subunits in the same subcellular fraction appeared constant under different experimental conditions (Fig. 3, $A-C$ ).

The identity of CKII subunits phosphorylated in situ in slice fractions was further verified on 2-dimensional immunoblots, using polyclonal anti-CKII antibodies, by comigration with purified cytosolic CKII phosphorylated in vitro with unlabeled ATP (results not shown). In Figure 2, the insets display immunostaining patterns of 50 and $60 \mathrm{kDa}$ subunits. Immunoreactive 50 and $60 \mathrm{kDa}$ bands comigrated with the in situ labeled 50 and $60 \mathrm{kDa}$ phosphoproteins in the different fractions.

The identity of CKII subunits in different hippocampal fractions was examined by immunoprecipitation experiments using anti-CKII antibodies. The major phosphorylated bands detected in immunoprecipitates corresponded to the 50 and $60 \mathrm{kDa}$ subunits of CKII (Fig. 4A, arrowheads). The immunoprecipitated $50 \mathrm{kDa}$ phosphoprotein was further analyzed by phosphopeptide mapping. Immunoprecipitated $50 \mathrm{kDa}$ phosphoproteins from all hippocampal fractions produced peptide maps which were similar to the in vitro phosphorylated $50 \mathrm{kDa}$ of purified CKII (Fig. 4B). Attempts to obtain phosphopeptide maps of the immunoprecipitated $60 \mathrm{kDa}$ phosphoprotein from slice fractions were unsuccessful due to its low recovery in immunoprecipitates. Nevertheless, the in situ phosphorylated 60 $\mathrm{kDa}$ subunit from 1-dimensional gels generated a phosphopeptide map similar to the in vitro labeled $60 \mathrm{kDa}$ of purified CKII (Fig. $5 B$, lanes 5 and 6).

Characterization of additional phosphoproteins. Hippocampal proteins phosphorylated under $\mathrm{Ca}^{2+} /$ basal conditions were analyzed by limited proteolysis. Peptide mapping of the $80-87 \mathrm{kDa}$ region of 1-dimensional gels of cytosolic fractions showed a pair of phosphopeptides at 13 and $9 \mathrm{kDa}$ that are characteristic of $87 \mathrm{kDa}$ substrate of protein kinase C (Wu et al., 1982; Fig. 5A, lane 2 ; open arrowheads). In comparison, peptide mapping of the same $M_{r}$ region from "SJ-enriched" TXi fractions yielded 35 and $10 \mathrm{kDa}$ phosphopeptide fragments characteristic of the sites in synapsin I phosphorylated by CKII and cAMP-dependent protein kinase, respectively (Huttner and Greengard, 1979; Fig. $5 A$, lane 4 , solid arrowheads). In TXs fractions, the same $M_{r}$ region produced a peptide map similar to the combined patterns of phosphopeptides observed in cytosolic and TXi fractions (Fig. 5A, lane 3).

Additional observations on in situ labeled CKII. The $60 \mathrm{kDa}$ subunit of CKII was found to be more highly phosphorylated in situ relative to the $50 \mathrm{kDa}$ subunit. This finding is in contrast to the relative levels of subunit phosphorylation observed in vitro (Fig. 2, $A$ vs $C, E$, or $G$ ). Higher ${ }^{32} \mathrm{P}_{\mathrm{i}}$ labeling of $60 \mathrm{kDa}$ relative to $50 \mathrm{kDa}$ subunit was observed in all fractions and predominantly under $\mathrm{Ca}^{2+} /$ basal and $\mathrm{Ca}^{2+} /$ high $\mathrm{K}^{+}$conditions. 
A
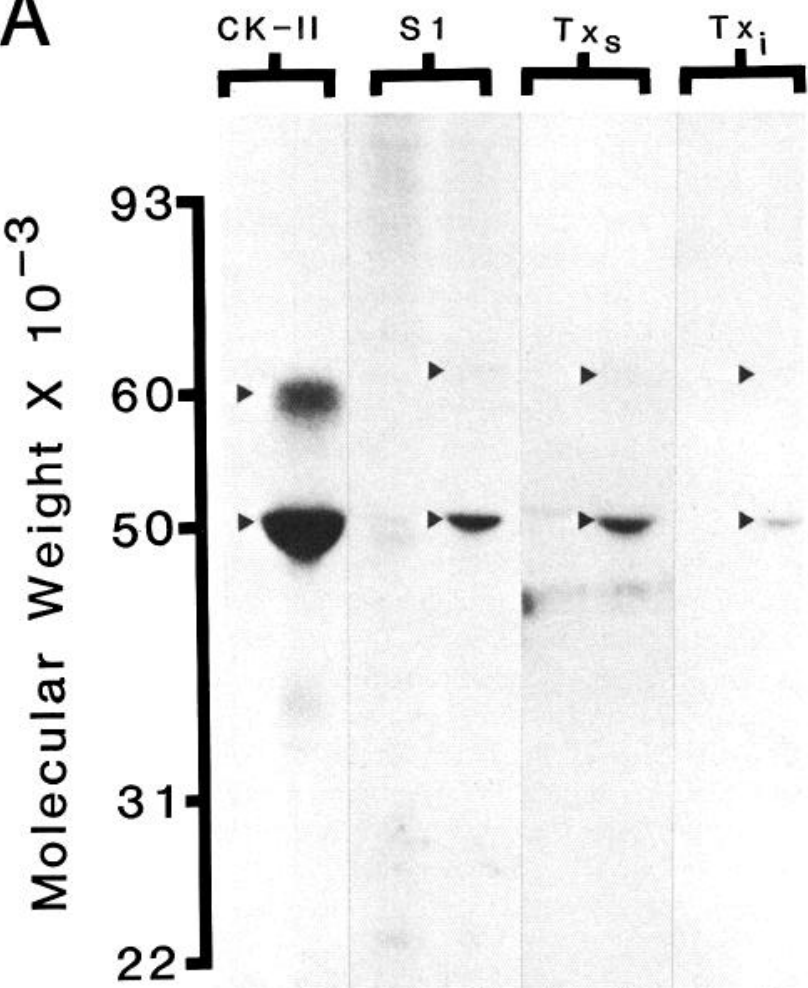

$\begin{array}{llllllll}1 & 2 & 1 & 2 & 1 & 2 & 1 & 2\end{array}$

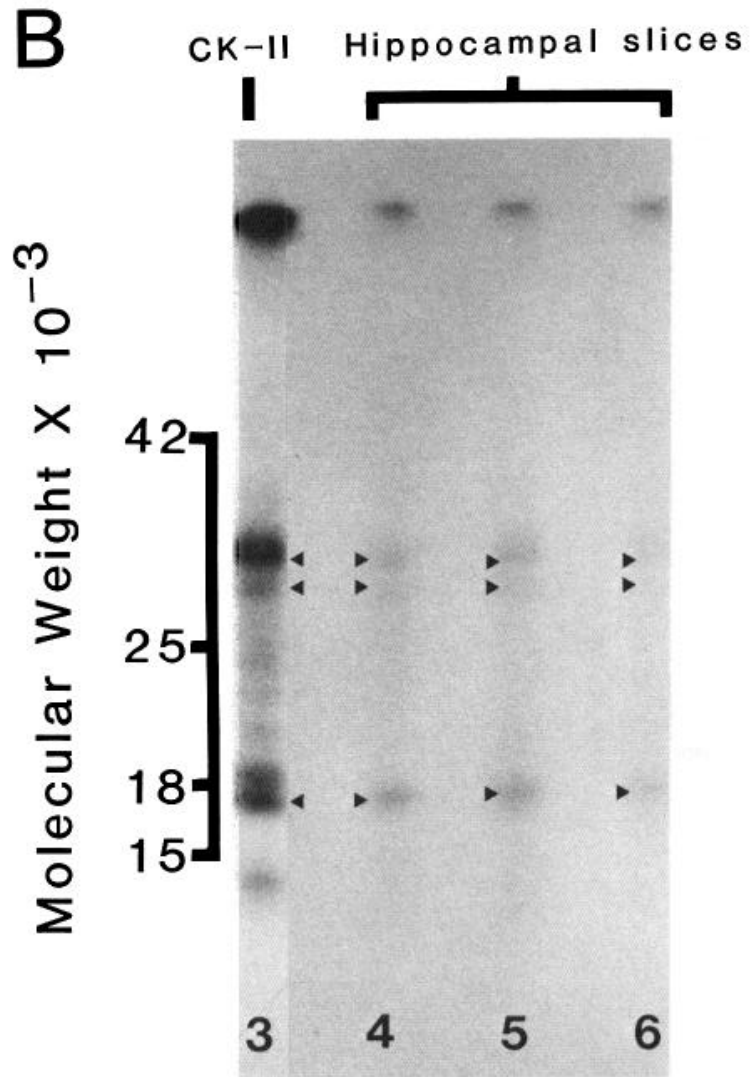

Figure 4. Immunoprecipitation analysis of in situ phosphorylated CKII. A, Aliquots of in vitro phosphorylated CKII (0.04 $\mu \mathrm{g})$ or hippocampal subcellular fractions, S1 $(12 \mu \mathrm{g})$, TXs $(24 \mu \mathrm{g})$, and TXi $(6 \mu \mathrm{g})$, were precipitated with either preimmune serum (lane 1) or anti-CKII antisera (lane 2 ) as described in Materials and Methods. Immunoadsorbed phosphoproteins were separated by SDS-PAGE and visualized by autoradiography; longer autoradiographic exposures (20 d) revealed ${ }^{32} \mathrm{P}$-labeled $58 / 60 \mathrm{kDa}$ subunit in each subcellular fraction (upper arrowheads in lane 2). B, Phosphopeptide maps obtained by limited proteolysis of immunoprecipitated $50 \mathrm{kDa}$ phosphoproteins in A; lane 3, purified CKII; lanes 4-6, combined subcellular fractions from depolarized hippocampal slices incubated in buffer containing $\mathrm{CaCl}_{2}($ lane 4$), \mathrm{CaCl}_{2}$ plus $\mathrm{A} 23187$ (lane 5), or $\mathrm{CaCl}_{2}$ plus verapamil (lane 6). Autoradiographic exposures were $6.7 \mathrm{~d}(A)$ and $22 \mathrm{~d}(B)$.

The increased in situ ${ }^{32} \mathrm{P}_{\mathrm{i}}$-incorporation associated with the 60 $\mathrm{kDa}$ subunit of CKII was found predominantly in TXs fractions and to a lesser extent in cytosolic fractions. Low levels of ${ }^{32} \mathrm{P}_{\mathrm{i}}$ incorporation into 50 and $60 \mathrm{kDa}$ subunits were observed in "SJenriched" TXi fractions, even though these fractions displayed the highest concentration of CKII subunits (Fig. 3).

A possible explanation for these apparent differences between in situ versus in vitro phosphorylation properties of CKII was that the $50 \mathrm{kDa}$ subunit of CKII is already highly phosphorylated in situ and any further stimulation would only result in a small increase in ${ }^{32} \mathrm{P}_{\mathrm{i}}$ incorporation. This hypothesis seems unlikely since back-phosphorylation of hippocampal proteins with $\left[\gamma-{ }^{32} \mathrm{P}\right]-\mathrm{ATP}$ following prior in situ incubations with unlabeled phosphate displayed substantial phosphorylation of both CKII subunits in a $\mathrm{Ca}^{2+} /$ calmodulin-dependent manner (Fig. $6 A$ ). As illustrated in Figure $6 A$, the 50 and $60 \mathrm{kDa}$ subunits phosphorylated in situ from slices incubated in buffers containing EGTA showed higher levels of back-phosphorylation (Fig. 6A, lanes 3 and 4,7 and 8,11 and 12) compared with their counterparts phosphorylated in situ under $\mathrm{Ca}^{2+}$ conditions (Fig. $6 \mathrm{~A}$, lanes 5 and 6, 9 and 10,13 and 14). This finding suggests that CKII was less phosphorylated in situ in slices incubated under EGTA compared with $\mathrm{Ca}^{2+}$ conditions. Back-phosphorylation of CKII in all subcellular fractions showed greater ${ }^{32} \mathrm{P}$-labeling of the 50 $\mathrm{kDa}$ compared with the $60 \mathrm{kDa}$ subunit, similar to the in vitro phosphorylation properties of CKII in purified synaptic junctions (Fig. 6A). Phosphopeptide mapping of the 50 and $60 \mathrm{kDa}$ phosphoproteins from 1-dimensional gels after back-phosphorylation yielded peptide maps that were similar to in vitro phosphorylated CKII subunits from purified synaptic junctions (Fig. $6 B$ ). The $50 \mathrm{kDa}$ region from $\mathrm{S} 1$ and TXs fractions generated an additional $7 \mathrm{kDa}$ phosphopeptide that indicated the comigration of another protein whose phosphorylation was not stimulated by $\mathrm{Ca}^{2+} /$ calmodulin. Indeed, phosphopeptide analysis of the $50 \mathrm{kDa}$ region from fractions back-phosphorylated in EGTA (Fig. $6 \mathrm{~A}$, lanes 3 and 7 ) revealed only the $7 \mathrm{kDa}$ peptide (results not shown).

\section{Discussion}

We have examined conditions that modulate the in situ phosphorylation of proteins in rat hippocampal tissue slices. We demonstrated that many proteins were phosphorylated in situ and their phosphorylation could be modulated by physiological factors such as divalent cations and membrane depolarization. Our results indicated that changes in protein phosphorylation under different conditions represented alterations in the in situ state of phosphorylation of individual proteins. First, no detectable protein dephosphorylation occurred during or after tissue homogenization. Second, nonspecific protein phosphorylation by released intracellular ${ }^{32} \mathrm{P}-\mathrm{ATP}$ following tissue 


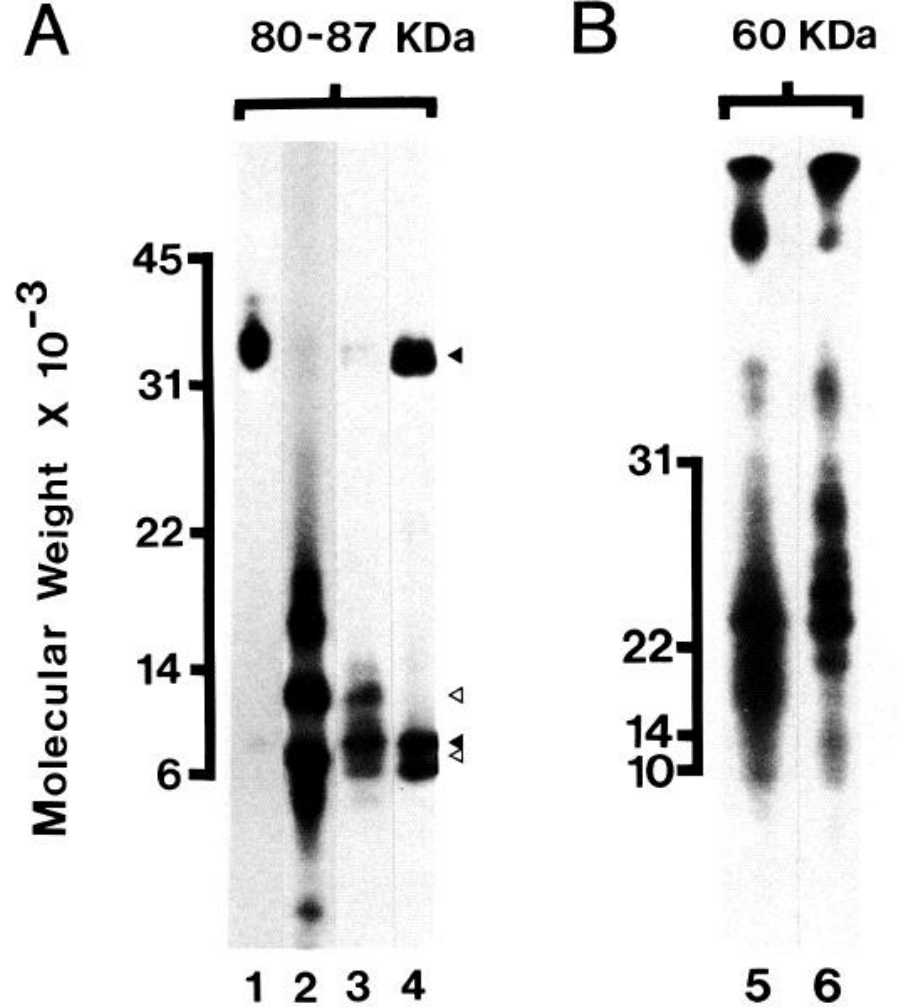

Figure 5. Autoradiograms of phosphopeptide maps using $S$. aureus V8 protease. A: Lane 1, synapsin I phosphorylated in vitro by purified CKII (solid arrowheads indicate the 35 and $10 \mathrm{kDa}$ phosphopeptides); lanes $2-4$, the $80-87 \mathrm{kDa}$ proteins labeled in situ from cytosolic (lane 2; open arrowheads indicate the 13 and $9 \mathrm{kDa}$ phosphopeptides), TXs (lane 3), and TXi (lane 4) fractions. B: Lane 5, $60 \mathrm{kDa}$ protein labeled in situ from a TXs fraction; lane 6, $60 \mathrm{kDa}$ subunit of CKII from purified SJ fraction phosphorylated in vitro.

homogenization was negligible. Our results showed that the presence of exogenous $\mathrm{Ca}^{2+}$ during both slice equilibration and prelabeling periods markedly increased the rate and/or extent of protein phosphorylation in all subcellular fractions. This apparent $\mathrm{Ca}^{2+}$-stimulatory effect was specific since $\mathrm{Ca}^{2+}$-channel blockers and the calmodulin antagonist W-13 significantly decreased ${ }^{32} \mathrm{P}_{\mathrm{i}}$ incorporation into hippocampal proteins following high $\mathrm{K}^{+} / \mathrm{Ca}^{2+}$ conditions. The concentrations of $\mathrm{Ca}^{2+}$-channel antagonists used were not unusually high since neural tissues are known to be more resistant to these compounds compared with cardiac or smooth muscle (Triggle, 1982). Although previous studies with synaptosomes demonstrated that a $60 \%$ decrease of $\mathrm{K}^{+}$-stimulated ${ }^{45} \mathrm{Ca}^{2+}$-uptake required $100-200 \mu \mathrm{M}$ verapamil or D-600 (Nachshen and Blaustein, 1979; Norris et al., 1983), we used higher concentrations $(250-500 \mu \mathrm{M})$ because of the greater penetration properties of tissue slices.

High- $\mathrm{K}^{+}$depolarization increased the in situ phosphorylation of many hippocampal proteins. Previous studies with synaptosomes (Krueger et al., 1977; Wu et al., 1982; Robinson and Dunkley, 1983a; Wang et al., 1988) demonstrated that depolarization-stimulated increases in protein phosphorylation were predominantly $\mathrm{Ca}^{2+}$ dependent. Our results with synapsin I under high $\mathrm{K}^{+} / \mathrm{Ca}^{2+}$ conditions agree with previous findings. In contrast to previous reports that high- $\mathrm{K}^{+}$depolarization in the presence of EGTA did not stimulate synapsin I phosphorylation (Krueger et al., 1977; Forn and Greengard, 1978), our results indicated that synapsin I phosphorylation was increased after slices were depolarized in EGTA compared with EGTA/basal conditions. Moreover, depolarization-stimulated phosphorylation of synapsin I in all subcellular fractions was greater (2- to 3-fold) in buffer containing EGTA versus $\mathrm{Ca}^{2+}$. This unexpected observation with synapsin I was also characteristic of B-50 (or GAP-43) in TXs and TXi fractions (Fig. 2). Although the precise mechanism for high- $\mathrm{K}^{+}$-stimulated and $\mathrm{Ca}^{2+}$-independent phosphorylation of synapsin I and B-50 is unclear, 2 explanations are possible. First, depolarization-stimulated but $\mathrm{Ca}^{2+}$-independent release of neurotransmitters has been described for CNS synapses (Haycock et al., 1978; Arias and Tapia, 1986). The subsequent activation of postsynaptic receptors could stimulate the hydrolysis of phosphatidylinositol to diacylglycerol and inositol trisphosphate $\left(\mathrm{IP}_{3}\right)$. Diacylglycerol could activate protein kinase $\mathrm{C}$, whereas $\mathrm{IP}_{3}$ could mobilize intracellular $\mathrm{Ca}^{2+}$ (Berridge and Irvine, 1984; Nishizuka, 1984). The resulting increase in $\mathrm{Ca}^{2+}$ would activate CKII (Dunkley et al., 1986; Robinson et al., 1987; Wang et al., 1988) and $\mathrm{Ca}^{2+} /$ calmodulin-dependent adenyl cyclase (Brostrom et al., 1975; Cheung et al., 1975). Stimulation of adenyl cyclase would increase intracellular cAMP and activate cAMP-dependent protein kinase. Activation of these kinases may explain the increased phosphorylation of synapsin $\mathrm{I}$ and B-50 under high $\mathrm{K}^{+} /$EGTA conditions. Furthermore, recent reports demonstrated that the $\mathrm{IP}_{3}$-induced effects on neuronal excitability are not inhibited by EGTA or other $\mathrm{Ca}^{2+}$ chelators (Dutar and Nicoll, 1988; Scholz et al., 1988). Our findings support the hypothesis that $\mathrm{IP}_{3}$ mobilization of intracellular $\mathrm{Ca}^{2+}$ in the presence of EGTA could result in the activation of protein kinases. Second, the phosphorylation of synapsin $\mathrm{I}$ in high $\mathrm{K}^{+}$/ $\mathrm{Ca}^{2+}$ has been shown to be maximal at 10-30 sec and then becomes rapidly dephosphorylated (Krueger et al., 1977; Forn and Greengard, 1978). Thus, the increased apparent phosphorylation of synapsin I, and possibly B-50, in high $\mathrm{K}^{+}$/EGTA could result from sustained phosphate incorporation in the absence of dephosphorylation compared with their phosphorylation and subsequent dephosphorylation in high $\mathrm{K}^{+} / \mathrm{Ca}^{2+}$. Since the present studies examined the effects of high $\mathrm{K}^{+} / \mathrm{Ca}^{2+}$ for only $1 \mathrm{~min}$, the rapid phosphorylation followed by dephosphorylation of these proteins would not have been observed. In this context, it is important to note that the $87 \mathrm{kDa}$ protein kinase $\mathrm{C}$ substrate and CKII became more highly phosphorylated in high $\mathrm{K}^{+} / \mathrm{Ca}^{2+}$ compared with high $\mathrm{K}^{+}$/EGTA; their increased labeling would share as a common denominator increases in intracellular $\mathrm{Ca}^{2+}$

Figure 6. Back-phosphorylation of hippocampal proteins with $\left[\gamma^{-32} \mathrm{P}\right]-\mathrm{ATP}$. Hippocampal proteins were initially phosphorylated in situ in buffers containing $\mathrm{Na}_{2} \mathrm{HPO}_{4}$ and no ${ }^{32} \mathrm{P}_{\mathrm{i}}$, plus EGTA or $\mathrm{Ca}^{2+} . A$, In vitro phosphorylation reactions $(10 \mu \mathrm{g}$ protein/reaction) were carried out as described in Materials and Methods in buffer containing EGTA or $\mathrm{Ca}^{2+}$ plus calmodulin $\left(\mathrm{Ca}^{2+} / \mathrm{CaM}\right)$. Cytosolic (lanes 3-6); Triton soluble (TXs, lanes 710); and Triton insoluble (TXi, lanes 11-14) subcellular fractions. Lanes 1 and 2 contain purified synaptic junction proteins. $B$, Phosphopeptide maps (limited digestion with V8 protease) of the 50 and $60 \mathrm{kDa}$ bands from back-phosphorylation reactions shown in lanes $2,4,8$, and 12 in $A$. Autoradiographic exposures were $5.5 \mathrm{hr}(A)$ and $96 \mathrm{hr}(B)$. 
A
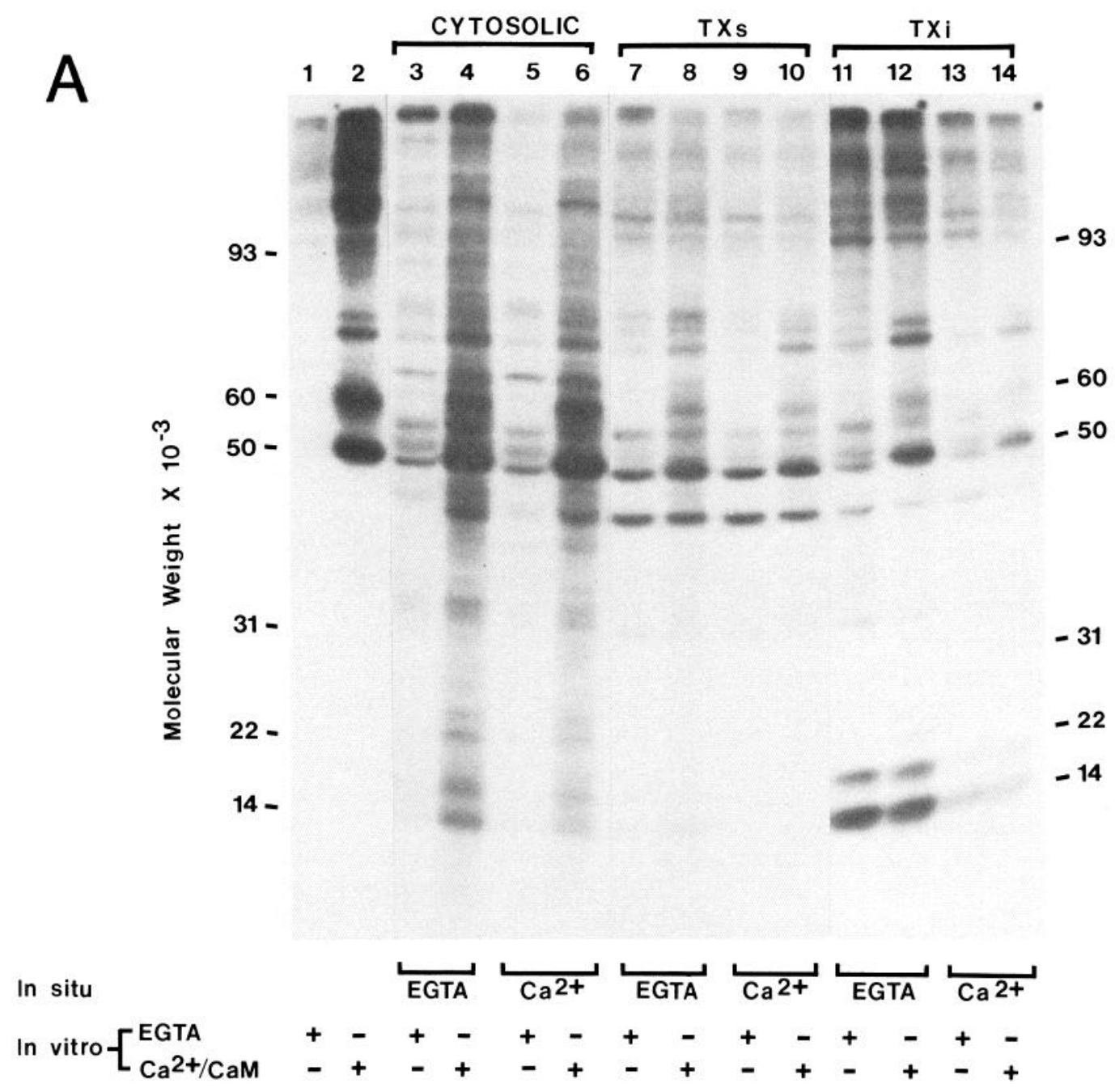

B
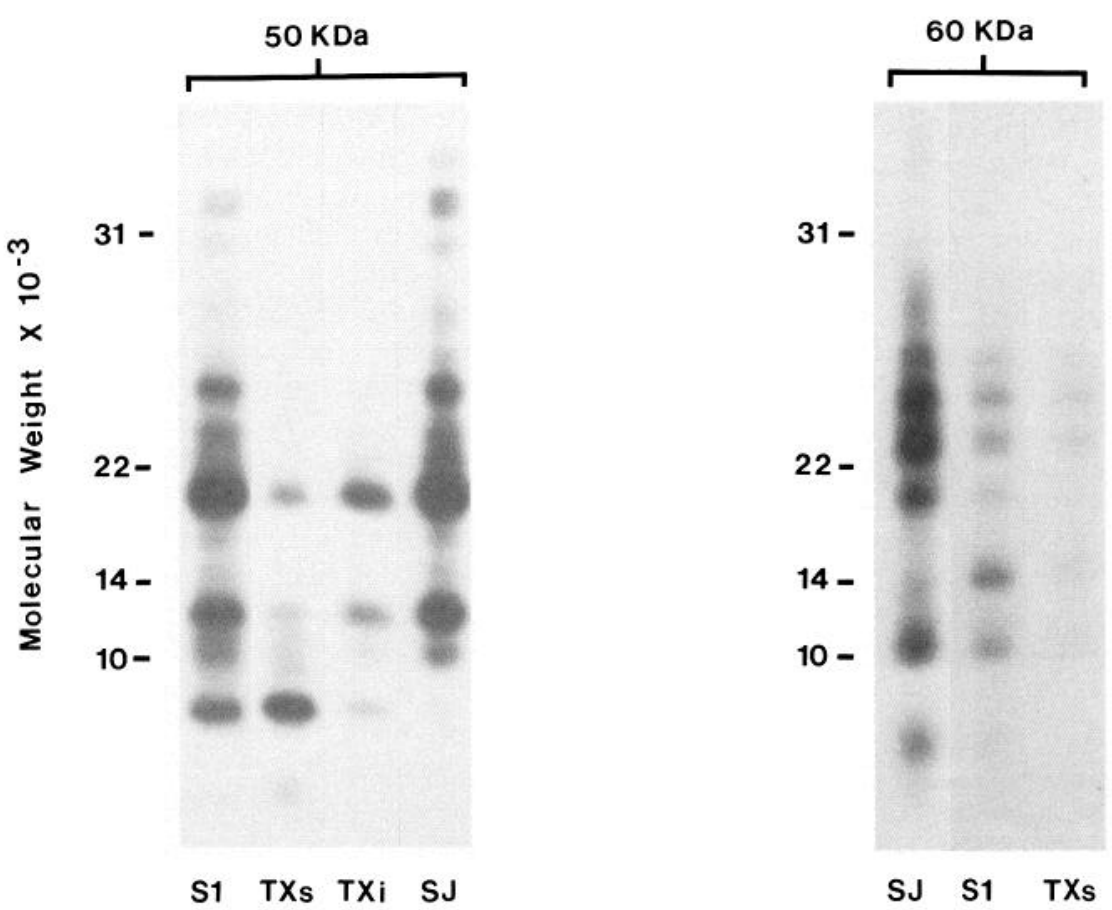
during high- $\mathrm{K}^{+}$depolarization. These results suggest the compartmentalization in hippocampal tissues of protein phosphorylation/dephosphorylation processes that are high $\mathrm{K}^{+} / \mathrm{Ca}^{2+}$ stimulated, on the one hand, versus high- $\mathrm{K}^{+}$stimulated and independent of extracellular $\mathrm{Ca}^{2+}$, on the other.

Many hippocampal proteins displayed $\mathrm{Ca}^{2+}$-stimulated dephosphorylation. Two cytosolic proteins, $96 \mathrm{~b}$ and $96 \mathrm{c}$, were dephosphorylated in a $\mathrm{Ca}^{2+}$ and depolarization-stimulated manner. Robinson et al. (1987) reported the $\mathrm{Ca}^{2+}$-dependent dephosphorylation of a synaptosomal protein designated P96 following depolarization and suggested that P96 may be a subunit of the neuronal calcium pump. However, it seems unlikely that P96 is identical to either $96 \mathrm{~b}$ or $96 \mathrm{c}$, despite their similar subcellular distribution and dephosphorylation properties. First, the phosphorylation of $\mathrm{P} 96$ was $\mathrm{Ca}^{2+}$ dependent and increased very little following high- $\mathrm{K}^{+}$depolarization. In contrast, the phosphorylation of $96 \mathrm{~b}$ and $96 \mathrm{c}$ was highest after depolarization in EGTA. Second, in contrast to P96, depolarization in $\mathrm{Ca}^{2+}$ resulted in the dephosphorylation of $96 \mathrm{~b}$ and $96 \mathrm{c}$. One possibility underlying the dephosphorylation of $96 \mathrm{~b}$ and $96 \mathrm{c}$ is the activation of the $\mathrm{Ca}^{2+}$-stimulated protein phosphatase type-2B (calcineurin), which is present at high levels in brain (Wallace et al., 1980; Ingebritsen et al., 1983). Although the functional consequence of $96 \mathrm{kDa}$ dephosphorylation is unknown, the dephosphorylation of the $42 \mathrm{kDa}$ protein ( $\alpha$-subunit of pyruvate dehydrogenase; see Fig. 2, $E, F$ ) results in its activation (Schaffer and Olsen, 1980).

Some changes in protein phosphorylation reported here could reflect differences in the specific activity of intracellular ATP following different prelabeling conditions. We think that this is unlikely for 2 reasons. First, the prelabeling conditions used here resulted in apparent steady-state levels of protein phosphorylation in slices incubated in $\mathrm{CaCl}_{2}$ or $\mathrm{Ca}^{2+}$-free media (see Materials and Methods). Second, although we have not determined the specific activity of ATP following the different labeling conditions, 2-dimensional gel analyses demonstrated that certain proteins were more highly phosphorylated in high $\mathrm{K}^{+}$ $\mathrm{Ca}^{2+}$, some were more highly labeled in high $\mathrm{K}^{+}$/EGTA, whereas the phosphorylation of many proteins appeared the same following either labeling protocol. These results indicate that the specific activities of ATP among the different labeling conditions were similar enough to support our conclusion that the observed differences in protein phosphorylation resulted from the differential activation of protein kinases and/or phosphatases.

Certain hippocampal proteins phosphorylated in situ were similar to those previously characterized in cortical synaptosomes labeled in vitro with ${ }^{32} \mathrm{P}_{\mathrm{i}}$ (Krueger et al., 1977; Robinson and Dunkley, 1983a; Dunkley et al., 1986) and cortical (Forn and Greengard, 1978) or hippocampal tissue slices (Browning et al., 1981) using back-phosphorylation assays with $\left[\gamma^{-32} \mathrm{P}\right]$ ATP. The 80 and $86 \mathrm{kDa}$ doublet appeared identical to synapsin I on the basis of molecular weight and isoelectric point. Phosphopeptide mapping of the in situ ${ }^{32} \mathrm{P}_{\mathrm{i}}$-labeled $80-86 \mathrm{kDa}$ doublet yielded 2 major phosphopeptides of 10 and $35 \mathrm{kDa}$ similar to those observed for synapsin I (Huttner and Greengard, 1979; DeCamilli and Greengard, 1986). The $10 \mathrm{kDa}$ peptide fragment is phosphorylated by cAMP-dependent protein kinase and/or $\mathrm{Ca}^{2+} /$ calmodulin-dependent protein kinase $\mathrm{I}$ and the $35 \mathrm{kDa}$ peptide fragment is phosphorylated by CKII (DeCamilli and Greengard, 1986). The acidic $87 \mathrm{kDa}$ hippocampal phosphoprotein was easily resolved from synapsin $\mathrm{I}$ in 2-dimensional gels; its phosphorylation was predominately $\mathrm{Ca}^{2+}$ dependent and occurred primarily in cytosolic fractions. These properties indicate that the $87 \mathrm{kDa}$ protein is the same as the $87 \mathrm{kDa}$ substrate of protein kinase $\mathrm{C}$ described by Wu et al. (1982).

The identity of the 50 and $60 \mathrm{kDa}$ subunits of CKII in different hippocampal fractions was confirmed by (1) comigration in 2-dimensional gels with purified CKII, (2) 1- and 2-dimensional immunoblots using polyclonal antibodies specific for CKII, (3) immunoprccipitation using CKII antiserum, and (4) peptide mapping of the immunoprecipitated $50 \mathrm{kDa}$ subunit. Based on its 2-dimensional electrophoretic mobility, the $55 \mathrm{kDa}$ phosphoprotein(s) appeared to correspond to $\alpha$-tubulin, which has been shown to be phosphorylated by CKII under certain in vitro conditions (Goldenring et al., 1983). The 49 kDa phosphoprotein was identified as B-50 or GAP-43, which are substrates of protein kinase C (Aloyo el al., 1983; Benowitz et al., 1987). Identification of $49 \mathrm{kDa}$ was based on its enrichment in TXs fractions, acidic $\mathrm{pI}$ and immunoreactivity on 2-dimensional immunoblots using anti-B-50 antibodies (Benowitz et al., 1987). The $42 \mathrm{kDa}$ phosphoprotein was identified as the $\alpha$-subunit of pyruvate dehydrogenase by the following criteria: (1) its comigration with phosphorylated $\alpha$-subunit of pyruvate dehydrogenase from crude mitochrondrial fractions in 2-dimensional gels (results not shown), and (2) its stimulated ${ }^{32} \mathrm{P}_{i}$ labeling in EGTA and dephosphorylation in $\mathrm{Ca}^{2+}$, both of which are consistent with the findings of Robinson and Dunkley (1983b). The 14 and $19 \mathrm{kDa}$ phosphoproteins were identified as the small and large myelin basic proteins, respectively (Sulakhe et al., 1980), based on their 2-dimensional gel patterns and comigration with phosphorylated myelin basic proteins from crude myelin fractions (results not shown). Among the many hippocampal proteins whose levels of in situ phosphorylation were increased in the presence of $\mathrm{Ca}^{2+}$ and further stimulated by high- $\mathrm{K}^{+} \mathrm{de}-$ polarization, none displayed the magnitude of increase (10- to 15 -fold) that was observed for the 48 and $45 \mathrm{kDa}$ phosphoproteins. Although the identity of these acidic proteins is unknown, their enrichment in cytosolic fractions may suggest their participation in important functions such as synthesis of neurotransmitters or the regulation of intracellular metabolism.

Phosphopeptide mapping provided additional information on the probable identity of hippocampal protein kinases that are active in situ. Partial proteolytic digestion of the $87 \mathrm{kDa}$ substrate of protein kinase $\mathrm{C}$ yielded phosphopeptides characteristic of its in vitro phosphorylation by this kinase. Peptidemapping analyses also indicated that synapsin I was phosphorylated by $\mathrm{Ca}^{2+} /$ calmodulin- and cAMP-dependent protein kinases. The activation of protein kinase $\mathrm{C}$ in situ was further supported by the ${ }^{32} \mathrm{P}_{\mathrm{i}}$ labeling of its substratc B-50. CKII activation in situ was evidenced by the apparent autophosphorylation of its 50 and $60 \mathrm{kDa}$ subunits and further supported by the phosphorylation of its specific site on the $35 \mathrm{kDa}$ peptide fragment of synapsin I. Our results confirm and extend the previous 1-dimensional gel results of Berman et al. (1984) and Gurd and Bissoon (1985), who demonstrated that the major postsynaptic density protein was phosphorylated following intracranial injection of ${ }^{32} \mathrm{P}_{\mathrm{i}}$. In contrast, Dunkley et al. (1986) reported that the phosphorylation of CKII in intact synaptosomes was extremely difficult to detect.

Our results demonstrated that CKII was phosphorylated in situ in an apparent $\mathrm{Ca}^{2+}$-dependent manner. The similarities between phosphopeptide maps of either 50 or $60 \mathrm{kDa}$ subunit indicated that many of the sites autophosphorylated in vitro are also modified by ${ }^{32} \mathrm{P}_{\mathrm{i}}$ in situ. Despite these similarities, we ob- 
served differences between in situ versus in vitro phosphorylatcd CKII. First, the in situ phosphorylation of the $60 \mathrm{kDa}$ subunit was greater relative to the $50 \mathrm{kDa}$ subunit. Our estimates indicate that the ratio of 60:50 $\mathrm{kDa}$ subunit phosphorylation following in situ labeling was approximately 5-10: 1. Under in vitro autophosphorylation conditions, comparable ratios of 60 : $50 \mathrm{kDa}$ phosphorylation is approximately 1.5:1 (Bennett et al., 1983; Lai et al., 1986; Kelly and Shenolikar, 1987). Second, phosphopeptide mapping revealed slightly different apparent autophosphorylation sites in either the 50 or $60 \mathrm{kDa}$ subunits labeled in situ versus in vitro. This finding suggests that the autophosphorylation sites characterized from in vitro studies may not apply per se to in situ conditions. Third, the phosphorylation of 50 and $60 \mathrm{kDa}$ subunits in SJ-enriched, Tritoninsoluble (TXi) fractions seemed largely refractory to in situ labeling conditions, although these fractions contained the greatest enrichment of CKII. The latter observation agrees with the previous in vitro studies demonstrating that the majority of CKII in SJs is not autophosphorylated (Rostas et al., 1986; Kelly et al., 1987) and suggests that this enzyme may serve, in part, as a structural, nonenymatic element in the postsynaptic density (Kelly and Cotman, 1978). On the other hand, the high $\mathrm{K}^{+}$ $\mathrm{Ca}^{2+}$-stimulated phosphorylation of the $60 \mathrm{kDa}$ found predominantly in TXs fractions suggests an enzymatic role of CKII in synaptic membranes. Although the precise subcellular origin of the Triton-soluble $60 \mathrm{kDa}$ subunit is unknown, previous in vitro studies suggest that it may be derived in part from $\mathrm{SJ}$-associated CKII (Kelly et al., 1987).

Estimates of the stoichiometry of autophosphorylation in situ require accurate determinations of the specific activity of ${ }^{32} \mathrm{P}$ ATP in the same subcellular compartments in which CKII resides. Although we have not attempted to determine the latter, the apparently high ratio of $60: 50 \mathrm{kDa}$ autophosphorylation observed in situ suggests that the $60 \mathrm{kDa}$ subunit of CKII may play a critical role in the kinase's autoregulatory properties. Recent in vitro studies have indicated that as little as $1-3 \mathrm{~mol}$ $\mathrm{P}_{\mathrm{i}} /$ mol holoenzyme converts the autophosphorylated kinase into a Ca ${ }^{2+} /$ calmodulin-independent protein kinase (Lai et al., 1986; Miller and Kennedy, 1986; Lickteig et al., 1988). Experiments with synthetic calmodulin-binding peptides indicate that the 60 $\mathrm{kDa}$ subunit has a greater affinity for calmodulin and suggest that this subunit may be preferentially autophosphorylated when CKII is activated (Kelly et al., 1988). Generation of the $\mathrm{Ca}^{2+}$ / calmodulin-independent form of CKII by preferential autophosphorylation of $60 \mathrm{kDa}$ may in turn lead to long-term increases in protein phosphorylation that may underlie synaptic plasticity (Miller and Kennedy, 1986; Lisman and Goldring, 1988). A recent study (Wang et al., 1988) did not support such an autoregulatory role for CKII in situ. Wang et al. (1988) found that the apparent activation of CKII in synaptosomes prelabeled with ${ }^{32} \mathrm{P}_{\mathrm{i}}$ did not sustain high levels of synapsin I phosphorylation during continued depolarization or after repolarization. These results may be explained by the transient $(2-10 \mathrm{sec})$ autoactivation of CKII to a $\mathrm{Ca}^{2+}$-independent form during high $\mathrm{K}^{+} / \mathrm{Ca}^{2+}$ depolarization of synaptosomes (Gorelick et al., 1988). It will be important to determine if the in situ autophosphorylation of CKII causes it to function as a $\mathrm{Ca}^{2+}$-triggered molecular switch in neurons.

\section{References}

Aloyo, V. J., H. Zwiers, and W. H. Gispen (1983) Phosphorylation of B-50 protein by calcium-activated phospholipid-dependent protein kinasc and B-50 protein kinase. J. Neurochem. 41: 649-653.

Arias, C., and R. Tapia (1986) Differential calcium dependence of $\gamma$-amino-butyric acid and acetylcholine release in mouse brain synaptosomes. J. Neurochem. 47: 396-404.

Bennett, M. K., N. E. Erondu, and M. B. Kennedy (1983) Purification and characterization of a calmodulin-dependent kinase highly concentrated in brain. J. Biol. Chem. 258: 12735-12744.

Benowitz, L. I., P. J. Apostolides, N. Perrone-Bizzozers, S. P. Finklestein, and $H$. Zwiers (1988) Anatomical distribution of the growthassociated protein GAP-43/B-50 in the adult rat brain. J. Neurosci. 8: 339-352.

Berman, R. F., J. P. Hullihan, W. J. Kinnier, and J. E. Wilson (1984) In vivo phosphorylation of postsynaptic density proteins. Neuroscience 13: 965-971.

Berridgc, M. J., and R. F. Irvine (1984) Inositol trisphosphate, a novel second messenger in cellular signal transduction. Nature 312: 315321.

Brostrom, C. O., Y.-C. Huang, B. M. Breckenridge, and D. J. Wolff (1975) Identification of a calcium-binding protein as a calcium-dependent regulator of brain adenylate cyclase. Proc. Natl. Acad. Sci. USA 72: 64-68.

Browning, M., M. F. Bennett, P. Kelly, and G. Lynch (1981) Evidence that the $40,000 \mathrm{Mr}$ phosphoprotein influenced by high frequency synaptic stimulation is the alpha subunit of pyruvate dehydrogenase. Brain Res. 218: 255-266.

Browning, M. D., R. Huganir, and P. Greengard (1985) Protein phosphorylation and neuronal function. J. Neurochem. 45: 11-23.

Cheung, W. Y., L. S. Bradham, T. J. Lynch, Y. M. Lin, and E. A. Tallant (1975) Protein activation of cyclic $3^{\prime}: 5^{\prime}$-nucleotide phosphodiesterase of bovine or rat brain also activates its adenylate cyclase. Biochem. Biophys. Res. Commun. 66: 1055-1062.

Cleveland, D. W., S. G. Fischer, M. W. Kirschner, and U. K. Laemmli (1977) Peptide mapping by limited proteolysis in SDS and analysis by gel electrophoresis. J. Biol. Chem. 252: 1102-1106.

DeCamilli, P., and P. Greengard (1986) Synapsin I: A synaptic vesicleassociated neuronal phosphoprotein. Biochem. Pharmacol. 35:43494357.

DeLorenzo, R. J., S. D. Freedman, W. B. Yohe, and S. C. Maurer (1979) Stimulation of $\mathrm{Ca}^{2+}$-dependent neurotransmitter release and presynaptic nerve terminal protein phosphorylation by calmodulin and a calmodulin-like protein isolated from synaptic vesicles. Proc. Natl. Acad. Sci. USA 76: 1838-1842.

Dunkley, P. R., C. M. Baker, and P. J. Robinson (1986) Depolarization-dependent protein phosphorylation in rat cortical synaptosomes: Characterization of active protein kinases by phosphopeptide analysis of substrates. J. Neurochem. 46: 1692-1703.

Dutar, P., and R. A. Nicoll (1988) Stimulation of phosphatidylinositol (PI) turnover may mediate the muscarinic suppression of the M-current in hippocampal pyramidal cells. Neurosci. Lett. 85: 89-94.

Erondu, N. E., and M. B. Kennedy (1985) Regional-distribution of type II $\mathrm{Ca}^{2+} /$ calmodulin-dependent protein kinase in rat brain. $\mathrm{J}$. Neurosci. 5: 3270-3277.

Forn, J., and P. Greengard (1978) Depolarization agents and cyclic nucleotides regulate the phosphorylation of specific neuronal proteins in rat cerebral cortex slices. Proc. Natl. Acad. Sci. USA 75: 51955199.

Goldenring, J. R., B. Gonzalez, J. S. McGuire, Jr., and R. J. DeLorenzo (1983) Purification and characterization of a calmodulin-dependent kinase from rat brain cytosol able to phosphorylate tubulin and microtubule-associated proteins. J. Biol. Chem. 258: 12632-12640.

Goldenring, J. R., J. S. McGuire, Jr., and R. J. DeLorenzo (1984) Identification of the major postsynaptic density protein as homologous with the major calmodulin-binding subunit of a calmodulindependent protein kinase. J. Neurochem. 42: 1077-1084.

Goldenring, J. R., C. G. Wasterlain, A. B. Oestreicher, P. N. E. de Graan, D. B. Farber, G. Glaser, and R. J. DeLorenzo (1986) Kindling induces long-lasting change in the activity of a hippocampal membrane calmodulin-dependent protein kinase system. Brain Res. 377: 47-53.

Gorelick, F. S., J. K. T. Wang, Y. Lai, A. C. Nairn, and P. Greengard (1988) Autophosphorylation and activation of $\mathrm{Ca}^{2+} /$ calmodulin-dependent protein kinase II in intact nerve terminals. J. Biol. Chem. 263: 17209-17212.

Gurd, J. W., and N. Bissoon (1985) Phosphorylation of the postsynaptic density glycoprotein gp 180. J. Neurochem. 45: 1136-1140. 
Haycock, J. W., W. B. Levy, L. A. Denver, and C. W. Cotman (1978) Effects of elevated $\left(\mathrm{K}^{+}\right)$o on the release of neurotransmitters from cortical synaptosomes: Efflux or secretion? J. Neurochem. 30:11131125.

Huttner, W. B., and P. Greengard (1979) Multiple phosphorylation sites in protein I and their differential regulation by cyclic AMP and calcium. Proc. Natl. Acad. Sci. USA 76: 5402-5406.

Ingebritsen, T. S., A. A. Stewart, and P. Cohen (1983) The protein phosphatases involved in cellular regulation 6. Measurement of type- 1 and type- 2 protein phosphatases in extracts of mammalian tissues; an assessment of their physiological roles. Eur. J. Biochem. 132: 297-307.

Kelly, P. T., and C. W. Cotman (1978) Characterization of tubulin and actin and identification of a distinct PSD polypeptide. J. Cell Biol. 79: 173-183.

Kelly, P. T., and S. Shenolikar (1987) Role of autophosphorylation in regulating calmodulin-dependent protein kinases. Methods Enzymol. 139: 690-714.

Kelly, P. T., T. L. McGuinness, and P. Greengard (1984) Evidence that the major postsynaptic density protein is a component of a calcium/calmodulin-dependent protein kinase. Proc. Natl. Acad. Sci. USA 81: 945-949.

Kelly, P. T., R. K. Yip, S. M. Shields, and M. Hay (1985) Calmodulindependent protein phosphorylation in synaptic junctions. J. Neurochem. 45: 1620-1634.

Kelly, P. T., S. Shields, K. Conway, R. Yip, and K. Burgin (1987) Developmental changes in calmodulin-kinase II activity at brain synaptic junctions: Alterations in holoenzyme composition. J. Neurochem. 49: 1927-1940.

Kelly, P. T., R. P. Weinberger, and M. N. Waxham (1988) Active site-directed inhibition of $\mathrm{Ca}^{2+} /$ calmodulin-dependent protein kinase type II by a bifunctional calmodulin-binding peptide. Proc. Natl. Acad. Sci. USA 85: 4991-4995.

Kennedy, M. B., M. K. Bennett, and N. E. Erondu (1983) Biochemical and immunochemical evidence that the "major postsynaptic density protein" is a subunit of a calmodulin-dependent protein kinase. Proc. Natl. Acad. Sci. USA 80: 7357-7361.

Krueger, B. K., J. Forn, and P. Greengard (1977) Depolarizationinduced phosphorylation of specific proteins, mediated by calcium ion influx, in rat synaptosomes. J. Biol. Chem. 252: 2764-2773.

Laemmli, U. K. (1970) Cleavage of structural proteins during the assembly of the head bacteriophage T4. Nature 277: 680-685.

Lai, Y., A. C. Nairn, and P. Greengard (1986) Autophosphorylation reversibly regulates the $\mathrm{Ca}^{2+} /$ calmodulin-dependence of $\mathrm{Ca}^{2+} / \mathrm{cal}-$ modulin-dependent protein kinase II. Proc. Natl. Acad. Sci. USA 83: 4253-4257.

Lickteig, R, S. Shenolikar, L. Denner, and P. T. Kelly (1988) Regulation of $\mathrm{Ca}^{2+} /$ calmodulin-dependent protein kinase II by $\mathrm{Ca}^{2+} / \mathrm{cal}-$ modulin-independent autophosphorylation. J. Biol. Chem. 263: 19232-19239.

Lisman, J. E., and M. A. Goldring (1988) Feasibility of long-term storage of graded information by the $\mathrm{Ca}^{2+} /$ calmodulin-dependent protein kinase molecules of the postsynaptic density. Proc. Natl. Acad. Sci. USA 85: 5320-5324.

Llinás, R., T. L. McGuinness, C. S. Leonard, M. Sugimori, and P. Greengard (1985) Intraterminal injection of synapsin I or calcium/ calmodulin-dependent protein kinase II alters neurotransmitter release at the squid giant axon. Proc. Natl. Acad. Sci. USA 82: 30353039.

Lowry, O. H., N. J. Rosenbrough, A. L. Farr, and R. J. Randall (1951) Protein measurement with the Folin phenol reagent. J. Biol. Chem. 193: 265-275.

Melchers, B. P. C., P. N. E. de Graan, L. H. Schrama, W. J. Wadman, F. H. Lopes de Silva, and W.-H. Gispen (1988) Synaptic potentiation and membrane phosphoproteins. Neurol. Neurobiol. 35: 307327.

Millcr, S. G., and M. B. Kennedy (1986) Regulation of brain type II
$\mathrm{Ca}^{2+} /$ calmodulin-dependent protein kinase by autophosphorylation: $\mathrm{A} \mathrm{Ca}^{2+}$-triggered molecular switch. Cell 44: 861-870.

Nachshen, D. A., and M. P. Blaustein (1979) The effects of some organic "calcium antagonists" on calcium influx in presynaptic nerve terminals. Mol. Pharmacol. 16: 579-586.

Nairn, A. C., H. C. Hemmings, Jr., and P. Greengard (1985) Protein kinases in the brain. Annu. Rev. Biochem. 54:931-976.

Nestler, E. J., and P. Greengard (1984) Protein Phosphorylation in the Nervous System, Wiley, New York.

Nishizuka, Y. (1984) Turnover of inositol phospholipids and signal transduction. Science 225: 1365-1370.

Norris, P. J., D. K. Dhaliwal, D. P. Druce, and H. F. Bradford (1983) The suppression of stimulus-evoked release of amino acid neurotransmitters from synaptosomes by verapamil. J. Neurochem. 40: 514-521.

O'Farrell, P. H. (1975) High resolution two-dimensional electrophoresis of proteins. J. Biol. Chem. 250: 4007-4021.

Robinson, P. J., and P. R. Dunkley (1983a) Depolarization-dependent protein phosphorylation in rat cortical synaptosomes: Factors determining the magnitude of the response. J. Neurochem. 41: 909-918.

Robinson, P. J., and P. R. Dunkley (1983b) The role of protein phosphorylation in nerve cell function. In Molecular Aspects of Neurological Disorders, L. Austin and P. L. Jeffrey, eds., pp. 345-348, Academic, Australia.

Robinson, P. J., R. Hauptschein, W. Lovenberg, and P. Dunkley (1987) Dephosphorylation of synaptosomal proteins P96 and P139 is regulated by both depolarization and calcium, but not by a rise in cytosolic calcium alone. J. Neurochem. 48: 187-195.

Rostas, J. A. P., R. P. Weinberger, and P. R. Dunkley (1986) Multiple pools and multiple forms of calmodulin-stimulated protein kinase during development: Relationship to postsynaptic densities. Prog. Brain Res. 69: 355-371.

Schaffer, W. T., and M. S. Olsen (1980) The regulation of pyruvate oxidation during membrane depolarization of rat brain synaptosomes. Biochem. J. 192: 741-751.

Scholz, K. P., L. J. Cleary, and J. H. Byrne (1988) Inositol 1,4,5-trisphosphate alters bursting pacemaker activity in Aplysia neurons: Voltage-clamp analysis of effects on calcium currents. J. Neurophysiol. 60: 86-104.

Sulakhe, P. V., E. H. Petrali, E. R. Davis, and B. J. Thiessen (1980) Calcium ion stimulated endogenous protein kinase catalyzed phosphorylation of basic proteins in myelin subfractions and myelin-like membrane fraction from rat brain. Biochemistry 19: 5363-5371.

Towbin, H., and J. Gordon (1984) Immunoblotting and dot immunoblotting: Current status and outlook. J. Immunol. Methods 72: 313-340.

Triggle, D. J. (1982) Chemical pharmacology of calcium antagonists. In Calcium Regulation by Calcium Antagonists, R. G. Rahwan and D. T. Witiak, eds., pp. 17-37, American Chemical Society, Washington, D.C.

Wallace, R. W., E. A. Tallant, and W. Y. Cheung (1980) High levels of a heat-labile calmodulin-binding protein $\left(\mathrm{CaM}-\mathrm{BP}_{80}\right)$ in bovine ncostriatum. Biochemistry $80: 1831-1837$.

Wang, J. K. T., S. I. Walaas, and P. Greengard (1988) Protein phosphorylation in nerve terminals: Comparison of calcium/calmodulindependent and calcium/diacylglycerol-dependent systems. J. Neurosci. 8: 281-288.

Wasterlain, C. G., and D. B. Farber (1984) Kindling alters the calcium/ calmodulin-dependent phosphorylation of synaptic plasma membrane proteins in rat hippocampus. Proc. Natl. Acad. Sci. USA 81: 1253-1257.

Wu, W. C.-S., S. I. Walaas, and P. Greengard (1982) Calcium/phospholipid regulates phosphorylation of a $\mathrm{M}_{\mathrm{r}}$ " $87 \mathrm{~K}$ " substrate protein in brain synaptosomes. Proc. Natl. Acad. Sci. USA 79: 5249-5253.

Yip, R. K., and P. T. Kelly (1986) Protein phosphorylation in hippocampal tissue slices. Soc. Neurosci. Abstr. 12: 1149. 